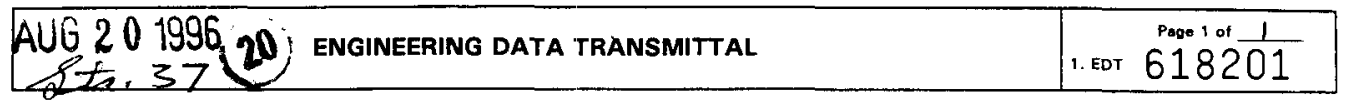

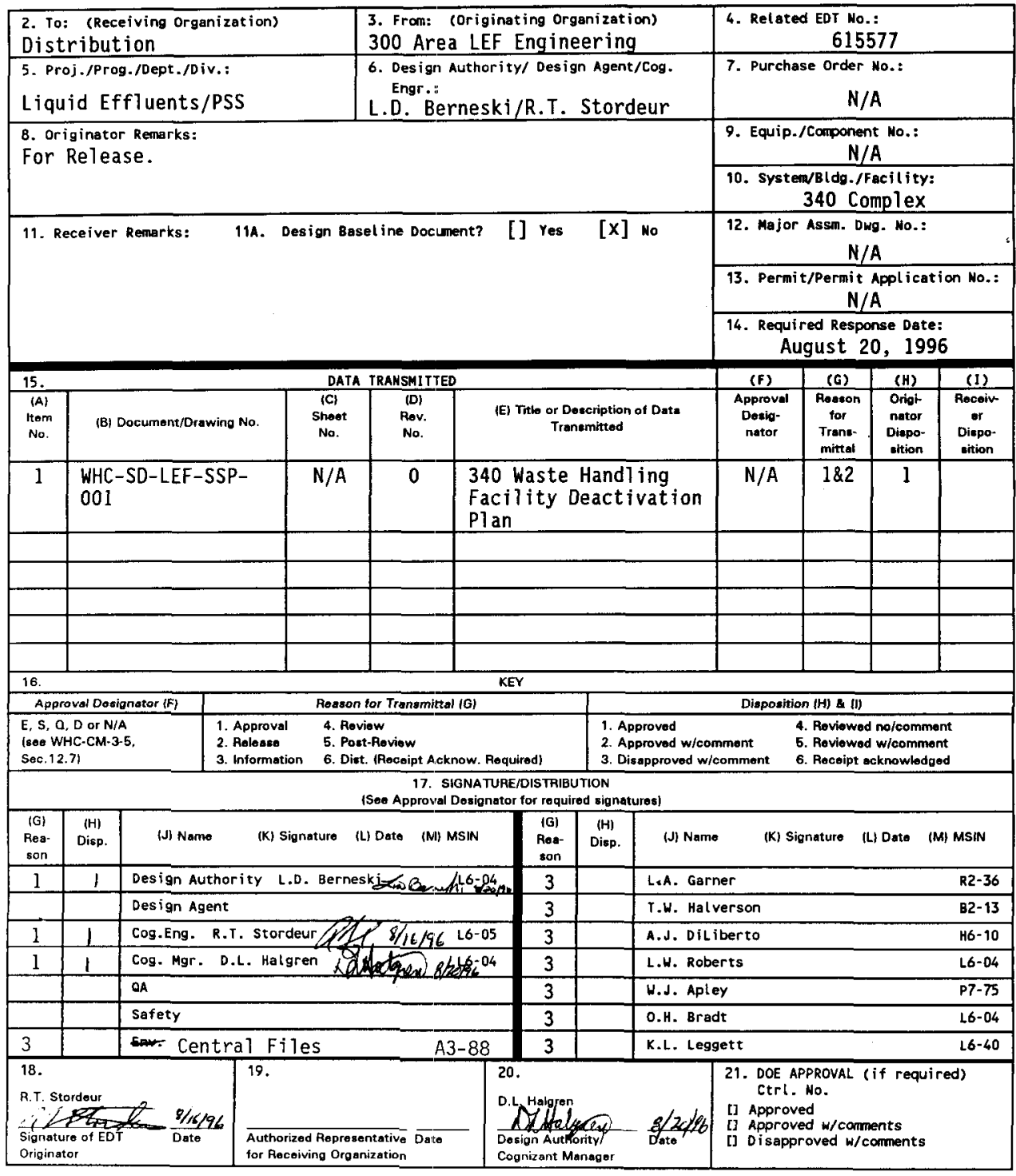

BD-7400-172-2(05/96) GEF097 


\title{
340 Waste Handling Facility Deactivation Plan
}

\author{
R.T. Stordeur, L.D. Berneski
}

Westinghouse Hanford Company, Richland, WA 99352

U.S. Department of Energy Contract DE-ACO6-87RL10930

EDT : 618201

Org Code: 86730

UC: 2050

B\&R Code: EW3130020

Charge Code: A234C

Total Pages: 48

Key Words: 340 Facility, radioactive liquid waste system, RLWS, retention process sewer, RPS, 307 basins, waste storage tanks, 300 Area, deactivation, shut-down, decommissioning, transition.

Abstract: This document provides an overview of both the present status of the 340 Complex (within Hanford's 300 Area), and of tasks associated with the deactivation of those segments dealing with radioactive, mixed liquid waste receipt, storage, and shipping. The plan also outlines actions needed to de-couple portions of the 340 Complex that will remain in service, including a replacement facility for required functions now fulfilled by systems proposed for deactivation. Task descriptions are presented, along with a detailed schedule for fiscal years 1997 through 2001 , a companion preliminary budget (focused more on the near term), and a list of key assumptions.

TRADEMARK OISCLAIMER. Reference herein to any specific comercial product, process, or service by trade name, trademark, manufacturer, or otherwise, does not necessarily constitute or imply its endorsement, recommendation, or favoring by the United states Government or any agency thereof or its contractors or subcontractors.

Printed in the United States of America. To obtain copies of this document, contact: WHC/BCS Document Control Services, P.O. Box 1970, Mailstop H6-08, Richland WA 99352, Phone (509) 372-2420; Fax (509) 376-4989.
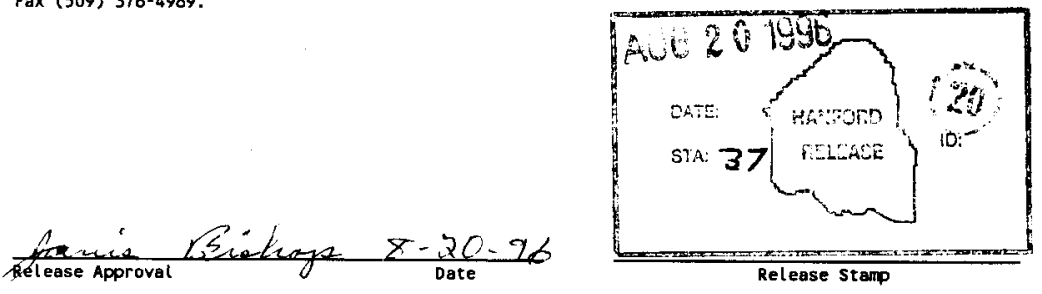


\title{
340 Waste Handling Facility \\ Deactivation Plan
}

\author{
WHC-SD-LEF-SSP-001 \\ Rev. 0
}

\author{
L.D. Berneski, R.T: Stordeur \\ 300 Area Liquid Effluent Process Engineering
}

August 1996 
WHC-SD-LEF-SSP-001, Rev. 0

This page intentionally without substantive content. 


\section{EXECUTIVE SUMMARY}

The 340 Complex provides radioactive, mixed liquid waste storage and transfer services for several 300 Area facilities. The Department of Energy - Richland Operations office requested (via performance based fee criteria \# 96-808) a plan for the deactivation of those portions of the 340 Complex dealing with the receipt, storage, and shipping of radioactive liquid waste system (RLWS) solutions. This portion of the 340 Complex includes: the 2 vault tanks; the 340-A building ( 6 above ground storage tanks); the east side of the 340-B building (used for waste load-out to rail tanker); and the RLWS components, upstream from 340 to the laboratory diverter stations. This plan also addresses portions of the 340 Complex that the shutdown indirectly affects yet still continue to have a mission, i.e., the retention process sewer (RPS), the 307 basins, and the west side of 340-B (used for solid waste staging and material storage).

The time period of primary interest for this plan is from the present until the respective facility systems are either de-coupled for continued operation, or terminated and then stabilized and/or cleaned-out. Due to its early stage in the shutdown process, the level of detail in this plan is of the rough order-of-magnitude type. The planning basis focuses on a tentative end-ofFY'98 final date for any new waste receipts at the vault. There are indications from Transition Projects that their deactivation of the 324 and 327 laboratories would be best served if 340 remained active, possibly until 2001 .

The objective of deactivation is to reduce physical risks and hazards by placing the facility in a passive/stable state such that the costs of both near and long-term surveillance and monitoring are minimized. This should be economical and consistent with the Site-wide mission goals, using existing technology and common sense engineering approaches. These actions should minimize the generation of waste/emissions, and limit worker exposure. The purpose of this plan is to provide both an overview of this process, as well as specific recommendations (along with schedule and budget estimates) for near term activities. 
The following activities are recommended (not chronological):

- Negotiate satisfactory "end points" with the receiving caretaker, for the condition of areas, structures, and equipment at the time of transfer.

- Prepare a project management plan (PMP) with detailed work breakdown structure to incorporate any new work scope and further refine the budget and schedule presented in this plan.

- Track and confirm assumptions presented in section 1.3; such as Pacific Northwest's critical 325 upgrade, the alterations for truck load-in at the 204-AR facility, the rail service situation, and the possible need for 340 beyond the projected shutdown date.

- Perform these specific tasks:

* Finalize the selection (proposed in section 3.1) and then implement the segregation of equipment/systems into those which are essential and must be maintained, and those which can be run-to-fail prior to shut-down. Categorize the configuration management documentation according to various disposition groupings.

* Isolate/inspect/clean-out $340-A, 340-B, 340 \mathrm{vault} / \mathrm{tanks}$, the 340 decontamination area, and upstream RLWS components as outlined in section 3.2 of this plan.

* De-couple RPS from RLWS system per plan (i.e., modify diverter/basin routings \& controls, and construct/assemble/permit a truck load-out and stand-by treatment facility at the 307 basins). (see sect. 3.3)

* Conceptualize/implement upgrades needed to facilitate surveillance \& maintenance phase (e.g., modify lighting, install remote surveillance systems, adjust HVAC, weatherize buildings, relocate alarms). (\$3.4)

A detailed schedule (see figure 4-1) summarizes these activities; and related, rough costs estimate are also presented (Table 4-1). The budget needed over the next 5 years for the above tasks is estimated at over $\$ 5 M$ above base operations funding. However, this information must be regarded as suitable for only preliminary budget planning, as changes in assumptions (rail availability, lab missions, waste volumes, regulations, etc.) could significantly impact these projections. Also, certain tasks must await the results of intervening work before they can be scoped with more confidence (e.g., the type and extent of upgrades still warranted after terminal cleanout to facilitate long term surveillance and maintenance). The PMP called for above, time, and subsequent decommissioning documentation out lined in section 1.2, will provide such detail. 
EXECUTIVE SUMMARY ......................

ABBREVIATIONS/ACRONYMS LIST ..................... vi

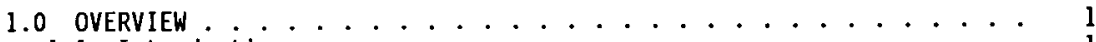

1.1 Introduction . . . . . . . . . . . . . . . . . . . 1

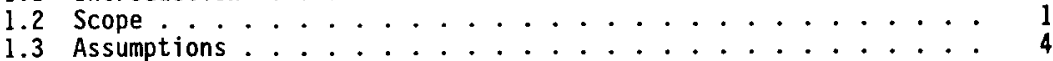

2.0 CURRENT CONDITIONS .......................... . . . . 7

2.1 Facility Description ................... . . . 7

2.2 Organization and Control .................. . 9

2.2.1 Management Organization . . . . . . . . . . . . . 9

2.2.2 Configuration Management . . . . . . . . . . . . . . 10

2.2.3 Records Management .................. . 10

2.3 Environmental Compliance . . . . . . . . . . . . . . . 11

2.3.1 Gaseous discharges . . . . . . . . . . . . . . . 12

2.3.2 Liquid discharges ... . . . . . . . . . . . . . 13

2.4 Safety . . . . . . . . . . . . . . . . . . . 14

2.4.1 Criticality ...................... 14

2.4.2 Safety Analysis ................... . . . 14

2.4.3 Contamination/exposure Contro1............. 14

2.4.4 Fire Protection .................. . . 15

2.4.5 Industrial Safety .................. 15

3.0 DEACTIVATION STRATEGY . . . . . . . . . . . . . . 17

3.1 Near Term Actions.................... . . . 17

3.1.1 SSC Related .................... . . 17

3.1.2 Management Related .. . . . . . . . . . . . . . 21

3.2 Facility Stabilization Actions . . . . . . . . . . . 21

3.2.1 Inventory Description ................ 22

3.2.2 Inventory Reduction Actions . . . . . . . . . . . . 23

3.3 De-coupling RPS from RLWS . . . . . . . . . . . . . . . . 24

3.3.1 Changes to Diverters and Associated Operational Controls . . 25

3.3.2 Basin Cover . . . . . . . . . . . . . . . . . . 27

3.3.3 Truck Load-out Station . . . . . . . . . . . . . . . . 27

3.3.4 Stand-by Treatment . . . . . . . . . . . . . . . . 28

3.4 Interim maintenance \& surveillance .............. . . . . 30

3.5 Budget process ....................... . . . . 31

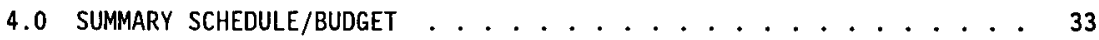

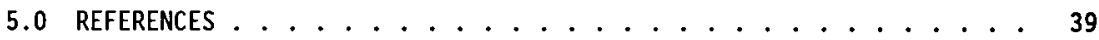

List of Figures/Tables

Figure 1-1 Generic Decommissioning Process .............. 3

Figure 2-1 Aerial View of 340 Facility ............... 8

Figure 3-1 340 Facility Process Flow Schematic . . . . . . . . . 19

Figure 4-1 Summary Schedule ...................... 34

Table 4-1 Summary Cost Estimates ..................... 38 
WHC-SD-LEF-SSP-001, ReV. 0

\section{ABBREVIATIONS/ACRONYMS LIST}

\begin{tabular}{|c|c|}
\hline $\begin{array}{l}\text { AGS } \\
\text { ALARA } \\
\text { ANSI } \\
\text { CFR } \\
\text { CX } \\
\text { D\&D } \\
\text { DOE } \\
\text { EA } \\
\text { ECOlogy } \\
\text { EPA } \\
\text { EPC } \\
\text { ERDA } \\
\text { FDC } \\
\text { HEPA } \\
\text { HLAN } \\
\text { HPS } \\
\text { HPT } \\
\text { HVAC } \\
\text { ISB } \\
\text { LEF } \\
\text { LLW } \\
\text { NEPA } \\
\text { NESHAPS } \\
\text { NFPA } \\
\text { NOC } \\
\text { NOI } \\
\text { PACific } \\
\text { Northwest } \\
\text { PHMC } \\
\text { PM } \\
\text { PS } \\
\text { PSE } \\
\text { QA } \\
\text { RCRA } \\
\text { RL } \\
\text { RLWS } \\
\text { RPS } \\
\text { SARP } \\
\text { SSC } \\
\text { TCO } \\
\text { TEDF } \\
\text { TPA } \\
\text { TSD } \\
\text { VE } \\
\text { WAC } \\
\text { WDOH } \\
\text { WHC } \\
\text { WH }\end{array}$ & $\begin{array}{l}\text { above ground storage } \\
\text { as low as reasonably achievable } \\
\text { American National Standards Institute } \\
\text { code of federal regulations } \\
\text { categorical exclusion (NEPA) } \\
\text { decontamination and decommissioning } \\
\text { U.S. Department of Energy } \\
\text { environmental assessment (NEPA) } \\
\text { State of Washington Department of Ecology } \\
\text { U.S. Environmental Protection Agency } \\
\text { end-point criteria } \\
\text { U. S. Energy Research and Development Agency } \\
\text { functional design criteria } \\
\text { high efficiency particulate air [filter] } \\
\text { Hanford local area [computer] network } \\
\text { Hanford plant standard } \\
\text { health physics technician } \\
\text { heating, ventilating: and air conditioning } \\
\text { interim safety basis } \\
\text { Liquid Effluent Facilities } \\
\text { low level waste } \\
\text { National Environmental Policy Act } \\
\text { National Emission Standards for Hazardous Air Pollutants } \\
\text { National Fire Protection Association } \\
\text { notice of construction } \\
\text { notice of intent }\end{array}$ \\
\hline
\end{tabular}




\subsection{OVERVIEW}

\subsection{Introduction}

The existing 340 Complex serves several 300 Area facilities which generate radioactively contaminated 1 iquid wastes, some of which are also contaminated with hazardous materials. Wastes can be transferred to the 340 Facility storage tanks by one of four routes: 1) direct from the radioactive liquid waste system (RLWS), the primary path; 2) via tanker trucks or drums; 3 ) via transfers from the 307 basins; or, 4) through diversions from the retention process sewer (RPS). The RLWS portion of the facility is classified as a nonreactor category III nuclear facility. The RPS/307 basins are nonnuclear. Section 2.1 provides more detail on these systems.

The need for this plan derived from a decision to abandon Project W-302, which was intended to bring the 340 waste tank system into compliance with RCRA tank containment requirements, and to improve system maintainability. Due to budget limitations and changing missions, a value engineering (VE) study and subsequent evaluations led to the decision that Pacific Northwest National Laboratory (Pacific Northwest) will modify the 325 Laboratory to provide for waste storage and a truck-based load-out/shipment system. The new 325 capability, plus the gradual phase-out of other facilities serviced, will al low the termination of 340 radioactive liquid waste receipt operations in the near future (see 1.3 assumptions).

The process of deactivating ${ }^{1}$ the 340 Facility should begin shortly, and will continue until transfer to either the transition projects organization or the environmental restoration contractor. This plan provides a list of guiding assumptions, a portrait of current operations, and a preliminary blueprint for deactivation. The purpose and basic schedule for deactivation are presented in the balance of section 1.0 .

\subsection{Scope/objectives}

This plan addresses the deactivation of those portions of the 340 Complex dealing with the receipt, storage, and shipping of RLWS solutions -- in particular: the vault; the 340-A building; the east side of the 340-B building; and the RLWS components upstream to the diverter stations. Other portions of the 340 Complex indirectly affected by the shutdown (e.g., RPS \& 307 basins), are also addressed. The time period for this plan is from the present (i.e., at plan issuance) until the respective facility systems are either de-coupled for continued operation, or terminated and then stabilized

\footnotetext{
"Deactivation", has been defined (WHC-EP-0895, draft B Plant Trensition PMP) as: "Activities associated with removing facility systems and/or areas from operational service with the intent of being ready for facility transition to either convert the facility for another use or move to permanent shutdown. These activities could include the removal of fuel, draining and/or de-energizing of systems, removal of accessible stored radioactive and hazardous materials, and other actions to place the facility systems and/or areas in a safe and stable condition so that a surveillance and maintenance program will able to most cost effectively prevent any unacceptable risk to the public or the envirorment until ultimate disposition of the facility." The same document defines "shutdown decision" as "A formal DOE-HQ documented determination that a facility is surplus thas no identified programatic use\}". Other sources (WHC-CM-6-1, EP-2.5) consider deactivation to follow a surplus declaration (post-shutdown), yet describe similar objectives and activities. The EM-60 "Facility Deactivation End Points Handbook" (DOE 1995b) indicates that "final shutdown" can occur during (after initial and before final stages of) deactivation.
} 
and/or cleaned-out. Since legal and regulatory requirements (see section 2.3) will remain in force throughout the deactivation phase, it is also within the scope of this plan to address related considerations.

The objective of deactivation is to reduce physical risks and hazards; placing the facility in a passive/safe state such that the costs of both near and long-term surveillance and monitoring (S\&M) are minimized. This should be done economically, and consistent with the Site-wide mission goals, using existing technology and common sense engineering approaches. These actions should minimize the generation of additional waste/emissions and limit worker exposure. Defense-in-depth practices should be employed to provide as many layers of protection as feasible and warranted; such as, eliminating hazards, providing containment, and furnishing effective monitors and controls.

Facility capabilities and/or features which are needed for interim S\&M or the final decommissioning should be preserved as appropriate. The facility status after deactivation will be negotiated to the satisfaction of the receiving caretaker. The end points need to be practical, quantitative, clear, and achievable. While many end points should be identifiable during early planning, it is still an iterative process -- whereby decisions/agreements will have to be periodically re-visited as deactivation proceeds.

As a means of placing this plan and the prior statements into perspective, Figure 1-1 and the following paragraphs offer a brief overview of the complete facility decommissioning process, including agreement on end-points, actual transition, long term maintenance \& surveillance, and final disposition and closure. Much of this process is out of scope for this plan. It is also possible that many of these steps could be consolidated or otherwise modified.

Assuming all possible missions for 340 have been exhausted, the operator will confer with HQ regarding issuance of a formal shut-down order. This process could be delayed until 340 is placed in stand-by status, but a more proactive approach is assumed here.

Typically after receiving the $H Q$ shut-down order the operating contractor opens negotiations with the Environmental Restoration (ER) contractor to establish End-Point Criteria (EPC) to meet ER acceptance requirements for receipt. The EPC document, along with a Transition Plan, serve to outline the functional steps/guidelines that must be pursued. These two documents are similar to the engineering study/functional design criteria phases of a capital project. The receiving organization may also wish to perform an assessment to characterize the program, compliance status, facility, state, and any other possible liabilities of completing a transfer.

Concurrent with the work on the EPC and Transition Plan, any necessary NEPA documentation is scheduled to begin. Currently a categorical exclusion is under development, although it is possible that an Environmental Assessment may be required.

A Project Management $\mathrm{Pl}$ an is prepared, along with a long-term Surveillance and Maintenance Plan (SMP). The SMP outlines the scope of the caretaker that occurs between the end of deactivation and the initiation of final D\&D. This SMP is employed by the Project Hanford Management Contractor (PHMC) until formal transition to ER. It is possible that various capital upgrade packages 
WHC-SD-LEF-SSP-001, Rev. 0

Figure 1-1 Generic Decommissioning Process

(compiled from Ecology, EPA, DOE, 1995)

Pre-decommissioning (largely the scope of this plan)

\begin{tabular}{|l|}
\hline Verify all future missions exhausted \\
\hline Initiate terminal clean-out \\
\hline HQ issues formal shut-down notice \\
\hline
\end{tabular}

\begin{tabular}{l} 
Decommissioning \\
\begin{tabular}{|l|}
\hline Transition Planning \\
\hline Develop Project Mgmt Plan \& undertake TPA negotiations \\
\hline Prepare \& submit Preclosure Work Plan \\
\hline Submit End-point Criteria Document \\
\hline Submit Surveillance and Maintenance Plan \\
\hline Surveillance and Maintenance Phase \\
\hline TPA Negotiations \\
\hline Periodic evaluations of dispositioning Priorities \\
\hline Conduct activities in accordance with S\&M Plan \\
\hline Disposition Phase \\
\hline Disposition Planning \\
\hline Develop Project Mgmt Plan \& undertake TPA negotiations \\
\hline Prepare \& submit Closure Plan \\
\hline Submit End-state Criteria Document \\
\hline Develop/implement procedures/plans to accomplish end-state criteria \\
\hline Verify end-state criteria \\
\hline
\end{tabular} \\
\hline
\end{tabular} 
WHC-SD-LEF-SSP-001, Rev. 0

will be identified to minimize long-term maintenance costs. A RCRA closure $\mathrm{pl}$ an is prepared if needed. The land may revert to, and be covered under, one of existing 300 Area CERCLA operable units.

The deactivation is completed and any 340 inventories or residuals are either cleaned or left in place per agreements stated in the EPC. A Turn-over Package is prepared before the actual transition to ER is final. This package includes historical facility data, engineering documentation on operating systems, regulatory permits, TPA commitments, characterization data, configuration information, operating and deactivation $10 \mathrm{~g}$ books, property records, safety documents, equipment lists, material inventories, etc. (DOE 1995b). This deactivation plan is not intended to satisfy that need.

\subsection{Assumptions}

This section lists the baseline assumptions for this $\mathrm{plan}$. These assumptions represent the most realistic and/or practical predictions available, and are not displayed in any particular order. These assumptions should be tracked, as changes could trigger review/updates of the plan, and/or identify areas to proceed with caution.

a) Applicable standby condition type -- per WHC-CM-1-3, MRP 6.15: initially a III (or Reserve, i.e., no further operational requirement determined; but not declared excess due to security, strategic plans, written program guidance, or project mission statements), with eventual roll over to a IV. (or Deactivated, i.e., excess plant and equipment; facility is available for decontamination and disposal actions).

b) Hanford rail system will operate until the added waste generated by the terminal clean-out of 340 facilities is shipped from $340-B$; and the new railcar SARP is not more restrictive.

c) Regulators allow for continued interim 340 operation.

d) This deactivation plan will be pursued in earnest, with Pacific Northwest ceasing discharge to the RLWS by the end of September 1998 (RL 1996, Pacific Northwest 1996a). Pacific Northwest obtains FY'97 funding to begin modifications at 325 . It should be noted there have been indications (Pacific Northwest 1996b and 1996c) that 2001 may. be a better date; however, any extension must be directed by RL.

e) Final waste shipment from 340 to 204-AR by September 2000 accommodating the terminal clean-out (TCO) phase.

f) After TCO and facility isolation, hazard classification will change from category 3 to "Other Industrial Facility".

g) PHMC continues to operate the RPS, using 307 basins, independent of 340 and RLWS termination.

h) 204-AR is modified to accept trucks by end of FY' 98 . 
WHC-SD-LEF-SSP-001, Rev. 0

i) PHMC/Pacific Northwest will concur on any volume increases or other source term changes in RLWS or RPS.

j) Existing major pieces of equipment will deliver adequate performance during the interim period, afforded longevity via routine preventive maintenance.

k) Cost reductions (e.g., staff or utilities) that relate to the termination of operations will be off-set during the deactivation period by activities such as isolation, clean-out, and maintenance. This, plus the fact that the RPS/307 side continues to function, means no significant decreases should be anticipated nor factored into the annual 0\&M cost between the near-term and interim period for budget projections.

1) Any new equipment and/or facilities specified shall be designed and constructed to facilitate periodic surveillance, interim decontamination, and/or maintenance as needed.

m) No decontamination and decommissioning (D\&D) nor environmental restoration of existing facilities or piping is warranted under the scope of this plan. Any waste piping systems that are removed from service shall be isolated in an environmentally acceptable manner. There are no significant operational surplus/excess materials for transfer or disposal. Questions associated with a 90-day clock dictating post shutdown TCO scheduling will be resolved.

n) The PHMC will proceed under existing constraints, and at least initially, will pursue recommendations put forth in this plan.

o) The present general funding outlook will not change.

p) Future changes in DOE orders will not significantly alter the means for carrying out this plan.

q) To minimize worker disruption and accommodate the parallel continuation of operations at the RPS/307 basins, existing 340 Facility operations and supporting personnel will cover the basic deactivation work in addition to activities required for normal operation. Matrixed support from the Transition Projects organization will be sought as appropriate. 
WHC-SD-LEF-SSP-001, Rev. 0

This page intentionally without substantive content. 
WHC-SD-LEF-SSP-001, Rev. 0

\subsection{CURRENT CONDITIONS}

This section describes present conditions, such as the current 340 Facility status related to physical plant, configuration control, management organization, and safety basis. Section 3.0 subsequently addresses proposed operational or physical modifications related to the shutdown at 340 .

\subsection{Facility Description}

The following provides a brief description of the buildings within the 340 Complex (see Figure 2-1), and the associated liquid waste distribution piping systems. The 340 Complex includes the $340,340-A$, and $340-B$ buildings.

The 340 Building was originally constructed in the early 1950's and houses the sampling hood, decontamination area, equipment room, control room; closely coupled to a below grade concrete vault. The vault houses two - 57 kiloliter (15,000 gallon) stainless steel tanks, and has removable concrete cover blocks. In the early 1960's an addition was added to the 340 Building which included a garage and load-out facility (WHC 1992b). The total area of the original 340 , the annex, and vault, is 4530 s.f.'.

The 340-A Building (1350 s.f. $)^{2}$ sits partially below grade and houses six 30 kiloliter $(8,000 \mathrm{gal}$.) stainless steel tanks within a concrete berm. The tanks are currently available as backup storage for the vault tanks.

The $340-B$ Building $(3200 \mathrm{~s}, \mathrm{f} .)^{2}$ is termed the rail load-out facility. The building was initially constructed to accommodate two $76 \mathrm{kiloliter}(20,000$ gal.) rail tank cars. Currently, only the east side can receive rail cars. The tracks on the west side have been removed and this area is only used for storage. The two sides are now divided by a concrete shielding wall; which projects along the south end of the east side, extending protection to the 340 control room.

The RLWS is composed of encased stainless steel piping connecting the 340 vault tanks to the waste generators. It is used to collect liquid mixed wastes. The primary facilities generating 1 iquid waste discharged to the RLWS system are the $324,325,326,327$, and 329 buildings. Other generator facilities transfer containerized wastes via these connected facilities or directly to the 340 complex. The generators are responsible for ensuring that strict waste acceptance requirements are met.

The liquid mixed waste is collected at the 340 Complex and periodically transferred to a rail tank car in 340-B East, for transport to double shell tanks (via the 204-AR Waste Unlaading Facility) in the 200 Area.

The 340 Building is provided with a ventilation system servicing all of the rooms except the control and mechanical equipment rooms. Air fiows from uncontaminated areas toward areas with a potential for contamination. The

\footnotetext{
2

These square footage numbers were obtained from "Past Practices Technical Characterization study -300 Area -- Hanford Site", WHC-MR-0388, (WHC 1992b). [Note that Soft Reporting/ttanford PeopleCore/ WHC Building and Structure List, gives different areas: $340-4470$ s.f., 340-A - 1370, and 340-B - 1200 .

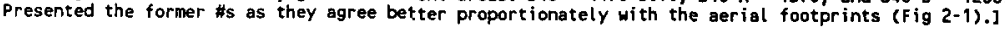


Figure 2-1 Aerial View of 340 Facility

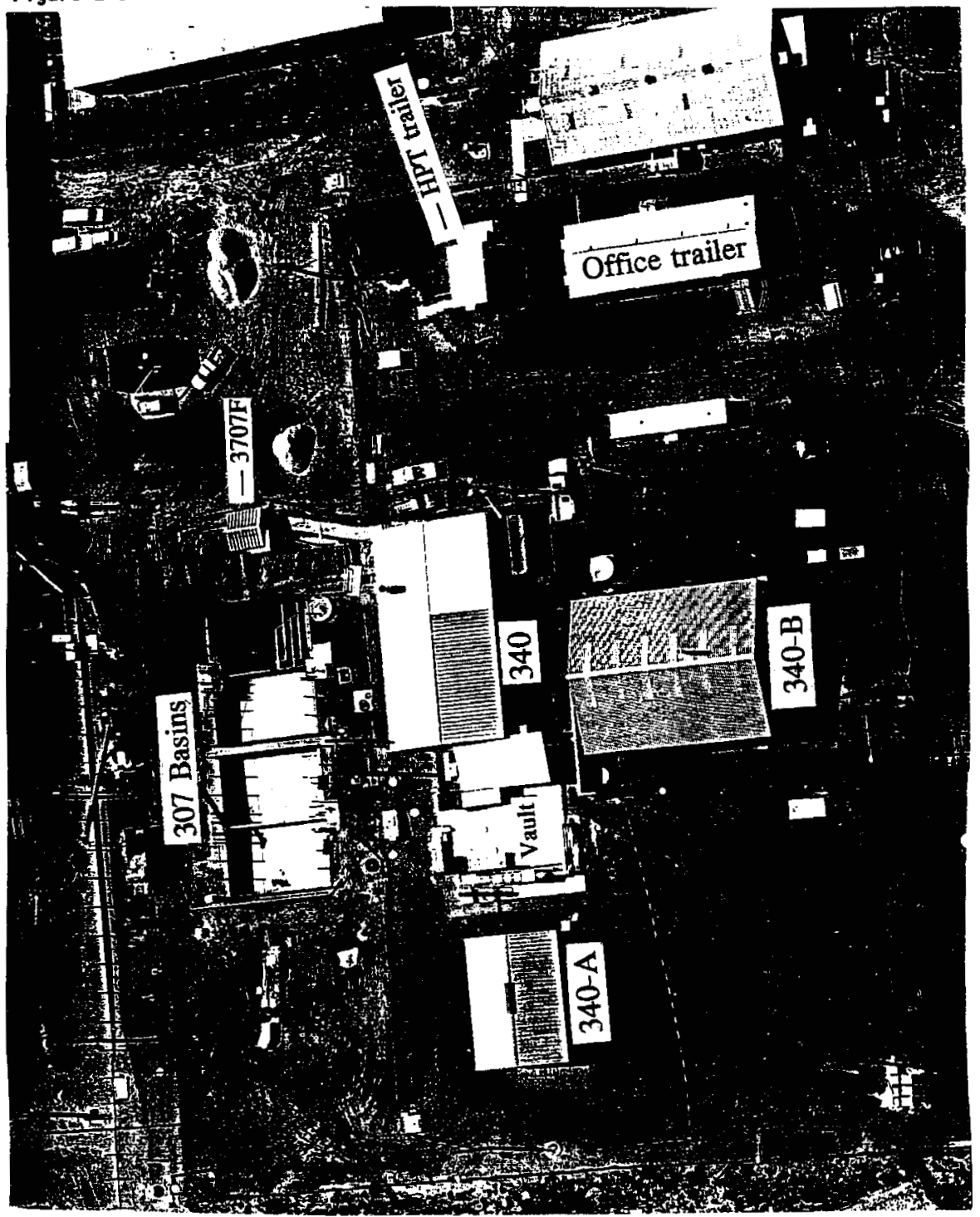


potentially contaminated areas are filtered through a single stage of HEPA filters. Exhaust from this area combines with exhaust from the change-room, truck lock, and operator office and is filtered through two stages of HEPA filters prior to discharge to the environment.

The 340 Vault and tanks are serviced by a common ventilation. Supply air is electrically heated in the winter to provide freeze protection. The exhaust discharges through a stage of dust stop filters, two-stage HEPA filters, and two exhaust fans located just east of the vault. A charcoal absorber stage is also in line. During normal use the fans are alternated with one in standby. A control damper on the vault $l i n e$ is used to maintain a higher vacuum in the tanks than in the vault. The off-gas line from the tanks contains a demister ahead of the tie-in to the filter system.

The RPS system serves as a collection system for non-hazardous process wastewater which is potentially radioactively contaminated. The RPS system includes underground piping, the 307 Basins, and four diverter stations. The 307 Basins were constructed during the same time frame as the RLWS and 340 Complex. The RPS diverters are capable of routing the wastes to either the RPS or the RLWS, and are located in the basements of the $324,325,326$, and 327 laboratories. The 326 diverter station monitors the combined flow from the 326 and 329 Buildings. These diverters were upgraded in 1996 with more sensitive beta/gamma monitors (WHC 1995a).

The 307 Basins currently consist of four 190 kiloliter (50,000 gallon) basins with associated valves, pumps, and pump controls. However, only half (or $-25,000$ gallons each) is useful capacity due to the location of the inlet pipes. Project W-345 (WHC 1993a) re-lined the basins and provided the system with a batch-release capability. Wastewater determined to be unacceptable for the 300 Area TEDF (WHC 1994h) can be transferred to the 340 Facility vault storage tanks.

\subsection{Organization and Control}

\subsubsection{Management Organization}

The 340 Complex is now managed by the Westinghouse Hanford Company for DOE. Facilities generating waste received at 340 are operated by WHC or the Pacific Northwest National Laboratory. Such an arrangement requires constant communication and cooperation between the waste generator and waste manager (WHC 1993b). The RLWS Disposal Approval Request system has been established to support this process.

WHC-IP-1000, 300 Area Liquid Effluent Facilities Administration (WHC 1994d), outlines policy for conduct of operations, general administration, engineering and work control.

340 is managed at the director level under the Liquid Effluent Services organization. The 300 Area Liquid Effluent Facilities (LEF) manager oversees operations and maintenance at both 340 Complex and the TEDF. Immediate control for the $340 \mathrm{Facility}$ is under the Facility Operations unit. LEF groups providing support to both facilities include the 300 Area LEF Maintenance/Work Control and the 300 Area LEF Engineering units. The training 
requirements are delineated in the Training Implementation Matrix: 340 Waste Handling Facility, (WHC 1995b).

The 340 Facility normally has an operations manager, 2 operators, and a Health Physics Technician (HPT) assigned to complete routines, monitoring and other assigned tasks. Additional operators are assigned to the facility as necessary. Similar resource allocation is made for work control and engineering support, and any additional support is assigned as required.

The HPTs are responsible for the day-to-day field implementation of the radiation protection program. MO-741 serves as the local HPT office and survey station. Other safety (nuclear, industrial, fire, criticality) oversight is provided both within LES or by other safety groups.

Maintenance crafts (millwrights, pipefitters, electricians, instrument specialists, carpenters) are matrixed from ICF Kaiser Hanford Company. Maintenance work is now managed using the formal job control system (JCS) outl ined by WHC-CM-1-8 (WHC 1995d) and supplemented by WHC-IP-1217 (WHC 1996e). This system provides semi-automated coordination between requestors, planner schedulers, crafts and reviewers, to assist in the tasks of originating, screening, assigning, performing and tracking the work, plus any post-completion testing. (see 3.1.2 for anticipated work control changes)

Execution of the WHC Quality Assurance program to provide oversight that designs, construction, testing, and operations meet regulatory requirements is conducted by LES QA specialists.

\subsubsection{Configuration Management}

The WHC configuration management program addresses design changes and controls with guidelines that cover changes to the facility documents (WHC-IP-1026, Engineering Practices Guidelines, WHC 1994a). The facility's cognizant engineers are responsible for identifying any additional documents, drawings, instructions, or procedures that are affected by acility change.

340 Facility drawings may not reflect as-built conditions for all systems. System walk-downs are employed as needed to ascertain correct configuration. As appropriate, subject to staff/funding availability or as a part of various system upgrades, key drawings are being updated.

The interim safety basis (WHC 1995e) provides a safety envelope for operations at the 340 Facility (also see 2.4). Changes resulting from any actions initiated by this plan will result in the document being updated via the engineering change procedure. Section 3.1.2 addresses other modifications to $340^{\prime}$ 's configuration management associated with facility transition.

\subsubsection{Records Management}

WHC policy is that all operations are to be conducted in accordance with written procedures. The requirement for complying with procedures is stated in WHC-CM-1-3, MRP 4.16, "Standards of Conduct." Compliance with the detailed instructions in procedures is essential for safe and reliable operation. The procedures comply with the applicable requirements of DOE Orders $4330.4 \mathrm{~A}$ and 5480.19 , as stated in the requirements of WHC-CM-3-5, Document Control and 
Records Management Manual, Section 12.0, "Document Control," and Section 12.5, "Working Level Procedure Control," and WHC-CM-4-2, Section 6.0, "Document Control." WHC-IP-1000 (WHC 1994d), Section 3.1, defines details of procedure use, review, changes, etc. for 300 Area LEF. A facility regulatory file has been established in accordance with WHC-CM-7-5 (WHC 1996f) section 5.7 .

These policies apply to all facilities and organizations that require the use of procedures for guidance and control of day-to-day activities. The 340 Facility controls, maintains, and modifies its procedures to achieve the highest standards of safety, efficiency, and excellence in conduct of operations. The procedures are kept up-to-date and readily available for the users, through a careful review and approval process. In addition to procedures, operator aids and timely orders are employed to further assist and inform operating staff.

Operating logs are kept which document facility events and personnel actions. Daily surveillance data sheets are used for specific instruments or devices. Daily operating Reports are electronically distributed. A required reading program is in place. Maintenance and calibration records are retained by the work control group. Work control packages are periodically archived, unless needed to support routine/recurrent activities. Records of solid waste designations and shipments are retained as required.

The Facility Evaluation Board conducts appraisals of WHC facilities to verify compl iance with DOE Order 5482.1B, Environment, Safety and Health Appraisal Program. Examples of activities covered by this organization include readiness reviews, design reviews, audits and appraisals, facility inspections, and operational surveillance and self assessments. The facility and operations are routinely assessed to verify compliance with the intent of meeting applicable codes, standards, and regulations.

WHC-IP-1000 (WHC 1994d) section 1.8 establishes an internal assessment program to promote continuous improvement of operations. These assessments are either conducted by qualified in-house personnel or are requested from support organizations. Findings are prioritized and corrective actions tracked. Information is periodically trended to identify any specific areas that may require additional management attention.

The 340 Complex, via the RLWS, typically collects from 11 to 38 kiloliters $(3,000$ to 10,000 gal.) every 90 days. Additional volume could be generated as a result of diversions from the RPS. Sampling of this waste is periodic and is consistently performed concurrent with rail car shipments. Data on individual RLWS transfers is maintained by both Pacific Northwest and 300 Area LEF. This data consistentiy contains volume, chloride, gross radionuclide, and $\mathrm{pH}$ information.

\subsection{Environmental Compliance}

The 340 Facility is managed as a less than 90 day waste accumulation area. Waste shipments are made on a time rather than a volume basis, given the available storage and rail tanker capacities, along with normal RLWS waste accumulation rates. 
WHC-SD-LEF-SSP-001, Rev. 0

A management strategy was developed as part of negotiations for a Tri-Party Agreement (Ecology, EPA, and DOE 1989) milestone (M-32-09). It commits 340 operations to perform specific activities which afford protection to the environment without either physical upgrades to the secondary containment ${ }^{3}$, nor the administrative actions such as daily visual inspections in radiation areas.

Built in 1953, many design features now required or encouraged under RCRA were employed within the 340 tank system. These features include the use of stainless steel tanks/piping, tanks with top penetrations, mostly welded joints, seamless jet pumps, additional containment structures, and use of liquid level and leak detection instrumentation. The 340 tanks and interconnecting piping have acceptably completed integrity assessments (WHC 1996b).

Concerning NEPA coverage, ERDA 1538 evaluated and "allows" current operation of liquid effluent streams in the 300 Area. Any alteration of routing or transportation of these liquid waste streams within the 300 Area and transporting up to the 200 Area plateau would require a new NEPA evaluation.

The following two subsections summarize both gaseous and liquid discharges associated with the 340 facility.

\subsubsection{Gaseous discharges}

The 340 Complex has three gaseous emission stacks. They are the tank vent system exhaust (340-NT-EX), the 340 Building Facility stack, and the 340-B East ventilation stack.

\section{Tank Vent System Exhaust (340-NT-EX)}

The 340 tank vent exhaust system provides air ventilation to the 340 Vault, 340 Vault tanks, and the 340-A Building tanks. Drawing H-3-34404 (WHC 1996d) provides an airflow diagram of the system. Supply air is electrically heated in the winter to provide freeze protection. The exhaust system discharges through a stage of dust stop filters, two-stage HEPA filters, and two exhaust fans and stack, located just east of the vault. The capability exists for the addition of activated charcoal adsorbent into the exhaust treatment train. The charcoal filters were used in the past, primarily for the control of potential iodine-131 releases.

Stack effluent flow rate is measured continuously, with annual verification. The average flow rate is $50 \mathrm{~m}^{3} / \mathrm{min}\left(1,800 \mathrm{ft}^{3} / \mathrm{min}\right)$. The stack effluent is sampled using a calibrated isokinetic sampling system. The record sampler contains filter media to sample and measure gross alpha, gross beta, radioiodine, as well as specific isotopes, which are analyzed by Pacific Northwest (WHC 1996g).

\footnotetext{
3

Note Project W-302 (mentioned in 1.1) was intended to provide for this and had been designed to bring the main 340 waste storage system into compliance with RCRA requirenents. W-302 was validated in the spring of 1995 as a 1997 Line Item; however, because of budget limitations, no capital funds were authorized. A value engineering (VE) study was conducted to look at options, along wi th two follow-up studies advocated by the VE team. The resulting recommendations of Pacific Horthwest/WHC (and subsequently supported by RL) provided both the impetus and foundation for this deactivation plan.
} 
Detailed information regarding the 340-NT-EX stack and compliance with applicable regulations (EPA 1989, EPA 1991) are provided in WHC-EP-0544 (WHC $1995 \mathrm{C}$ ) and the 340 FEMP (WHC 1996C).

\section{Building Stack}

The 340 Building Stack (340-DECON) exhaust system provides air ventilation to the truck 1ock, operator office, change-rooms, decontamination, and sampling hood.

Drawing H-3-52425 (WHC 1990a) provides an airflow diagram of the system. The 340 Building has a ventilation supply system, an evaporative cooling system, an electric heating system, and an exhaust system servicing all the rooms except the control and mechanical equipment rooms. The exhaust system consists of two-stage HEPA filters, an exhaust fan, and a stack that is located above the change rooms. Airflow from the decontamination area hood, sink, and sump pass through a stage of HEPA equivalent filters before the two-stage HEPA filters.

Stack effluent flow rate measurements are performed annually and the average flow rate is $200 \mathrm{~m}^{3} / \mathrm{min}\left(7,100 \mathrm{ft}^{3} / \mathrm{min}\right)$. Stack effluent is sampled using a calibrated isokinetic sampling system. The record sampler contains filter media to sample and measure gross alpha and gross beta. Stack sampling occurs quarterly. The sample medium consists of Versapor 3000TM filter paper for particulates. The sample medium is analyzed by Pacific Northwest.

\section{B East Ventilation Stack}

The 340-B East Ventilation Stack (340-B-BLDG) exhaust system provides air ventilation to the $340-B$ East Building. This ventilation system is required to be operated when containment is being broken to connect a railcar to facility piping and during waste transfers. The facility is not equipped with a supply air system.

Drawing H-3-34404 (WHC 1996d) provides an airflow diagram of the system. The ventilation system consists of a pre-filter, HEPA filter, exhaust fan, and stack located in the west side of the building.

Stack effluent flow rate measurements are performed annually and the average flow rate is $50 \mathrm{~m}^{3} / \mathrm{min}\left(1,800 \mathrm{ft}^{3} / \mathrm{min}\right)$. The stack effluent is sampled using a calibrated isokinetic sampling system, which is operated when the powered exhaust system is operational. The sample medium consists of Versapor 3000TM fjlter paper for particulates and are analyzed by Pacific Northwest for gross alpha and gross beta.

\subsubsection{Liquid discharges}

Several sources discharge liquid from the 340 Complex. Most of these waste streams contain no radioactive or hazardous materials (other than household materials such as off-the-shelf cleaners used for cleaning bathrooms) and are therefore not monitored. These non-monitored effluent streams are:

- Sanitary sewage from the 340 Complex, discharges via the 300 area system 
WHC-SD-LEF-SSP-001, Rev. 0

- Mechanical equipment cooling water drain discharges onto the asphalt outside the mechanical equipment room (from an evaporative cooler)

- An air conditioner condensate drain discharges onto the asphalt outside the 340 Building control room

- $K-3$ ventilation system (serving the 340 decon area) cooling water drain discharges to the process sewer (from an evaporative cooler)

- Storm water discharges to the process sewer from accumulation areas near the 340 Building entrance and 340 control room.

Two liquid discharges containing or having a potential to contain regulated materials, the RLWS and the RPS, have been addressed in section 2.1.

\subsection{Safety}

The current safety bases (Berneski 1995 \& WHC 1995e) address unacceptable risks appropriate to their respective foci (RPS \& 340 Facility), including fire, explosions, criticality, natural occurrences, industrial accidents, and exposure to radiation/toxins, noise, and electric shock. The 340 interim safety basis (ISB) quantifies the operating safety envelope and establishes safety requirements that assure compliance within a Hazard Category 3 classification. Due to the limited remaining active life of the 340 Facility, this ISB will continue to serve in piace of a Safety Analysis Report. The 340 ISB requires an annual update. An unreviewed safety questions process will be used to evaluate changing conditions at the facility and maintain the safety basis in an up-to-date configuration.

\subsubsection{Criticality}

The 340 Facility is presently classified as an Isolated Facility per WHC-CM-429, the Nuclear Criticality Safety Manual (WHC 1994b, WHC 1996a). This category identifies facilities that contain or could contain more than $3 \%$ of a minimum critical mass of fissionable material, but no more than $1 / 3$ of an MCM.

\subsubsection{Safety Analysis}

Safety classification of systems, components, and structures shall meet the requirements stated under WHC-CM-4-46, Section 9.0. On the basis of recent changes in that manual, the ISB Rev 1 (undergoing review at RL) exempts all system, component, and/or structures from any safety classification.

As low as reasonably achievable (ALARA) practices are followed, and job safety analyses are performed to ensure minimal employee exposure to hazards. An unreviewed safety questions process is administered to ensure that any new practices or configuration changes to the facility do not exceed or effect the safety envelope/basis.

\subsubsection{Contamination/exposure Control}

The 340 Facility (RLWS portion) is a hazard category 3 , nuclear facility (WHC 1995e). The vault tanks and related monitoring and control equipment and all 
other systems, structures, and components fall below requirements for the Safety Class category. The RPS/307 basin system is non-nuclear (Berneski 1995).

At least one upset condition in the past caused a serious release to the environment. This incident was remediated "to the extent possible" and corrective actions were taken to prevent the reoccurrence of similar incidents. The incident involved a contaminated soil column discovered on October 31 , 1977, beneath a tee in the radioactive liquid waste line near the 340 Building (Hall 1978). An estimated 90 percent of the contamination was removed during an excavation that extended down to $17 \mathrm{ft}(6 \mathrm{~m})$ below ground level.

Because of this incident, all of the RLWS piping is now required to be stainless steel pipe encased in reinforced epoxy pipe. The flow of waste through the RLWS piping is controlled by valves at critical points between the generating facilities and the 340 Building. These valves are located in covered concrete valve boxes.

No excavation work requiring worker proximity to radionuclide contamination is expected during the early decommissioning phases at 340 . However, added worker exposure is probable during the removal of residual waste inventories from the various storage tanks. All controls warranted to afford protection from potential radionuclide releases will be implemented. Shielding of the tanks and tank cars reduce worker exposure to ALARA levels.

\subsubsection{Fire Protection}

The fire detection and protection systems have been recentiy evaluated by a Fire Hazards Analysis (Roberts, 1995). Fire protection meets the "Improved Risk" criteria defined in and required by DOE Orders 6430.1A and 5480.7A and RLID 5480.7 (DOE 1989, DOE 1993), as well as the WHC fire protection manual (WHC, 1992a), and any applicable National Fire Protection Association codes. The fire alarm system is connected to the 300 Area fire alarm system. Fire extinguishers are installed in and around the facility.

Fire sprinklers will be installed in 340-B west to permit relaxation of storage capacity restrictions, allowing for greater beneficial use of this facility. After termination of routine mixed liquid waste activities at 340 , 340-B west can continue to handle solids generated from on-going RPS/307 operations, as well as terminal clean-out activities within the balance of the 340 complex. The separation between $340-B$ east and west (which includes a substantial shielding wall) should afford the possibility for a clean transition of the former load-out facility to ER.

\subsubsection{Industrial Safety}

Existing work procedures will continue to be implemented to ensure the safety of operating, maintenance, and any construction personnel in the area. Safety features (such as shower/eye wash stations, exit lighting, intercom phones) will be maintained until no longer substantially beneficial. 
WHC-SD-LEF-SSP-001, Rev. 0

The 340 site is not subject to through traffic. Existing roads will be maintained based on expected service and use. The existing fence will continue to provide adequate access control. 


\subsection{DEACTIVATION STRATEGY}

This section constitutes the core of the plan, covering the bulk of the predecommissioning steps outlined in section 1.2. A controlled notebook will be maintained as the facility shutdown logbook, to record activities as work is performed (WHC 1990b).

\subsection{Near Term Actions}

"Near term" is defined as the time period from the issuance of this plan until the routine mixed liquid waste receipts are discontinued. While this period of time is used to begin work on many of the tasks outlined in later sections, Section 3.1 only addresses changes of an operational nature.

\subsubsection{SSC Related}

There are several systems, structures, and components (SSC) essential to 340 operations. The SSC associated with those portions of the 340 Complex to be deactivated, must be maintained to ensure the facility is able to support the laboratories until the new load-out station is constructed. Systems with redundant capability or atypical access constraints could continue to be operated while being formally placed in a "run-to-fail mode", allowing focus on essential areas and reducing the overall maintenance cost for the facility.

The 340 facility currently has over 100 different preventive maintenance (PM) procedures. Many of these are on an annual or more frequent recall basis. Presented below are the systems considered essential and requiring preventive maintenance. PM on all other systems will be systematically evaluated for reduction or deletion. After Pacific Northwest provides replacement waste storage capabilities, the essential list will again be reassessed.

\section{Alarm System and Emergency Light ing}

The majority of the maintenance work for these systems consists of functional checks and PM, and as a safety issue will be continued.

\section{$\underline{\text { RLWS }}$}

The following are the major, critical components of the radioactive liquid waste system. Figure 3-1 depicts the relative orientation of many of these.

tanks TK-1, TK-2

at least three of the six AGS tanks

RLWS valves RL-: $1-5,15-25$

pumps TP-1, TP-2, TP-5

agitators $A G-1, A G-2$

oif pump OP-1

valve box leak detectors

tank level instrumentation

PMs associated with the RLWS equipment include pump/valve interlock checks, level measurement instrumentation calibration, and leak detector functional checks. Maintenance will continue on these components/systems. 
Heating Ventilation and Air Conditioning (HVAC)

Kl system \& associated sampling

K3 system \& associated sampling

The K-1 HVAC system services $340^{\prime}$ 's waste tanks. As long as there is a source term, this HVAC system will need to be operational. The $\mathrm{K}-3$ system services the 340 Building. Occasionally, generators deliver waste in containers for disposal into the waste tanks. This is completed in the 340 Decontamination Area. This area is also used to decontaminate and maintain equipment used in the facility. The $K-3$ system is required to operate so long as these activities take place. PMs on these $K-1$ and $K-3$ systems cover differential pressure gauges, fans, stack flow rates, and sampling instrumentation. Electric heaters provide freeze protection.

\section{Radiological Monitoring}

The number of instruments and their calibration/maintenance frequency is prescribed by Rad Con procedures. Changes may result from either changes within the facility or to the Rad Con requirements.

The vacuum system is used in obtaining stack samples. Even though it uses a lead/backup setup, which should allow time to respond to a failure of one side, the regulatory significance warrants continued preventive maintenance as long as the K1 \& K3 HVAC systems remain in service.

\section{Fire Protection}

Fire Protection is essential. PMs will continue to be performed during this near term period. (WHC 1992a)

\section{Balance of Plant}

This includes equipment such as pump TP-3 and its associated valves, and the K-2 (340-B east) ventilation, compressed air and process water systems. A "run-to-fail" mode of operation will be implemented for this type of equipment. With the exception of the $K l$ and $K 3$ ventilation systems, the 340 operations run in batches. It receives waste with prior notification and transfers out in a less-than-90 day time period. Loss of the "run-to-fail" systems can impact waste transfers, but through proper control of transfers, the facility should have time to respond. Some balance-of-plant items suggested for this category:

- TP-3 in the valve pit. The facility has operated without the TP-3 pump in the past. The maintenance on this system is expensive. It is located in a high dose rate, high contamination area.

- The compressed air system operates many of the RLWS valves within the 340 Facility and the level detection system. The system is equipped with a lead and backup compressor. This backup capacity should afford facility personnel adequate time to detect and replace a single compressor failure.

- The process water system is used to provide seal water to the RLWS pumps, flush lines and decontaminate the facility. Again these are batch 


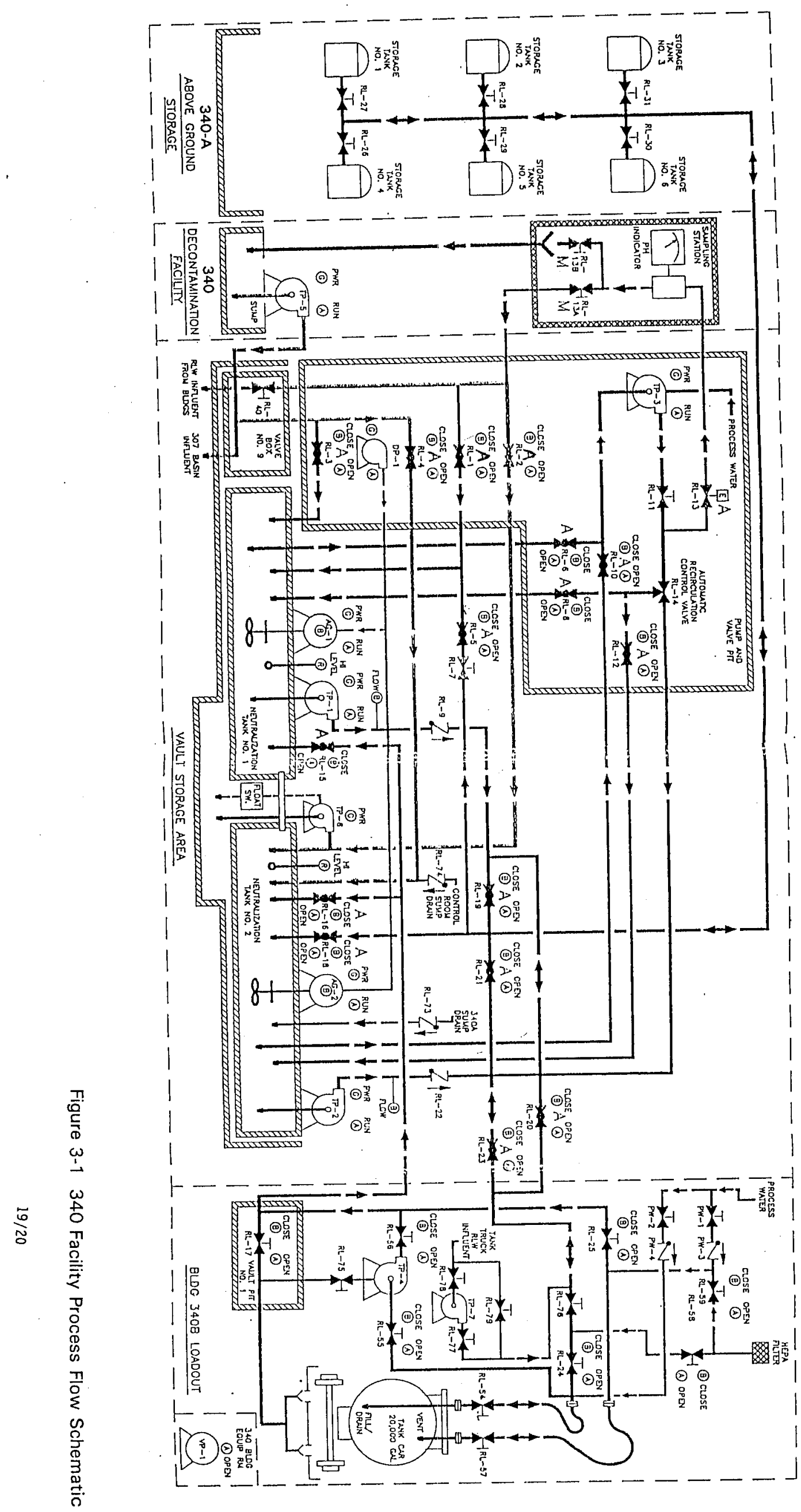

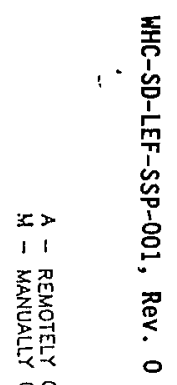


WHC-SD-LEF-SSP-001, Rev. 0

operations that the facility can control. The process water system is fairly new and not located inside any radiologically controlled areas. Repairing equipment outside radiological areas in not normally a problem.

of course, there is some risk to the "operate to fail" mode. The facility has experienced waste receipt without prior notification. Any waste in large quantities, such as a RPS divert, could require the facility to transfer waste to backup storage with little notification. Another risk is that while preventive maintenance cost may be reduced, there is the potential for repair cost to increase.

\subsubsection{Management Related}

Configuration management will be performed in accordance with the SSC's anticipated disposition category. Essential SSC remaining in operation will have their drawings, vendor information, and design bases maintained during this period. Documents required to support the design or use of those SSCs which are removed or disposed of, will be voided. Any usable surplus SSCs or SSCs transitioned for later disposition will include existing documentation in the turnover package. Documentation will be stored for any remaining SSCS whose disposition has not yet been determined.

The management of records will follow applicable sections in WHC-CM-3-5, Document Control and Record Management Manual (or its relevant PHMC successor) to ensure the availability of records needed to support the transition, surveillance and maintenance, and/or disposition phases of 340 decommissioning.

Maintenance work implementation/tracking will be conducted in a manner which retains all the essential elements expressed by WHC 1995d and 1996e, and any changes from the present JCS will be documented in revisions to section 4 of WHC-IP-1000 (WHC 1994d).

Self assessments will be performed in several areas to demonstrate continued policy compliance and to alert management to any deteriorating conditions.

The initial proposed changes will entail NEPA coverage, as will the eventual D\&D of 340. Pacific Northwest has been directed by RL to prepare a categorical exclusion $(C X)$, to cover many of the changes related to the transfer of storage and transport duties from 340 to.a Pacific Northwest facility (Pacific Northwest 1996c). The scope of this CX does not currently include al1 of the activities proposed later in this chapter, and it may yet be determined that an Environmental Assessment (EA) would more readily accommodate NEPA coverage for the complete integrated package; a possibility included in the 4.0 budget and schedule.

\subsection{Facility Stabilization Actions}

The preferred approach to stabilization is removal of the hazardous and/or radioactive inventory. If not possible, then the isolation and containment of contamination, followed by proper posting and documentation, will suffice until final disposition. The first sub-section identifies known areas of 
concern, followed in the next sub-section by the proposal for reducing the inventory and/or associated hazard as much as practicable.

\subsubsection{Inventory Description}

There are several areas within the RLWS that have inventories to be addressed. These include the 340-A tanks, 340-B East, vault tanks, the 340 Decontamination Area and the associated piping. The discussion of the inventory will include information on removable contamination. To give these values meaning, a point of reference may be helpful. In accordance with WHC Health Physics procedures an article with greater than 1,000 dpm beta/100 sq $\mathrm{cm}$ and/or $20 \mathrm{dpm}$ alpha/100 sq $\mathrm{cm}$ removable contamination must be managed as radioactive. All contamination data presented are given in $100 \mathrm{sq} \mathrm{cm}$ smears.

\section{0-A Tanks Radioactive Inventory.}

The 340-A tanks are used as backup storage to the vault tanks. Unlike the vault tanks, the 340-A tanks are not equipped with agitation. When waste is transferred to these tanks, most solids settle to the bottom of the tank. These solids are not resuspended by the draining process, allowing for a build up. This has lead to an increase in the dose rate surrounding the area and a need to address the potential for fissile material accumulations. In 1982, the facility evaluated the build up problem. Operations obtained samples of the solids and determined the volume of solids accumulated. The sampling effort was followed by a successful effort to flush the solids back to the 340 vault tanks. A similar sampling effort took place in 1995. Results indicate that the tanks conservatively contain approximately 1.5 inches of solids and have accumulated approximately 34 grams of fissile material. The sample results also show the presence of Cs-137 and Eu-154. These hard gamma producers contribute to the increase in dose rate for the surrounding area.

In addition to the soljds accumulation in the tanks, the valves in 340-A have had a problem with contamination. In the past year removable contamination has been as high as 100,000 dpm beta and 7,000 dpm alpha.

\section{0-B East Radioactive Inventory}

The 340-B East facility is used for loading RLWS into railcars for shipment to the 200 East Area. The facility is a surface contamination area. Data from 1995 shows contamination on the floor as high as $700,000 \mathrm{dpm}$ beta and $4000 \mathrm{dpm}$ alpha to $8000 \mathrm{dpm}$ beta and no detectable alpha following a decontamination effort. Every few years the facility undergoes a major decontamination effort to reduce levels. The majority of the valving is located on a platform $12 \mathrm{ft}$ above the floor. The platform floor is made of steel grating.

\section{The 340 Decontamination Area Radioactive Inventory}

The hood located in the 340 Building decontamination area has been used for obtaining samples from the Vault tanks. Contamination levels are near 500,000 dpm beta and $1000 \mathrm{dpm}$ alpha. The hood drains into the 340 decon sump. This sump is used for transferring containerized RLW into the vault tanks. The sump is routinely flushed after transfers and safety shower tests. Surveys from 1995 indicate contamination in the sump at levels near 20,000 dpm beta and $450 \mathrm{dpm}$ alpha. The floor area has remained stable with contamination 
WHC-SD-LEF-SSP-001, Rev. 0

levels near $1000 \mathrm{dpm}$ beta and less than $20 \mathrm{dpm}$ alpha. The samples lines from the hood are more contaminated. Dose rates from the lines range from 180 $\mathrm{mrem} / \mathrm{hr}$ to $120 \mathrm{mrem} / \mathrm{hr}$.

The 340 Vault Tanks Radioactive Inventory

The vault tank inventory with respect to solid accumulation is less certain than the 340-A tanks. Because the tanks are agitated, there is less of a concern than the 340-A tanks with solids buildup. The radioactive concentration of the waste has declined in recent years. Tank samples from 1989-1993 averaged four times higher in beta and 3 times higher in alpha than the more recent period between 1994-1996. Dose rates around the tanks have al so declined. In November 1990, dose rates under the tank exceeded 5000 $\mathrm{mrem} / \mathrm{hr}$ and the vault sump area dose rate was $2000 \mathrm{mrem} / \mathrm{hr}$. In 1995, the highest dose rate under the tank was $1500 \mathrm{mrem} / \mathrm{hr}$ and the sump area was 500 $\mathrm{mrem} / \mathrm{hr}$.

\section{Piping/Valve Boxes}

There are 15 valve boxes associated with the RLWS. Dose rates in the valve boxes vary. A survey in 1995 showed dose rate from less than detectable to 80 $\mathrm{mrem} / \mathrm{hr}$. There is al so removable contamination in some valve boxes. Most valve boxes indicate less than detectable. Valve box 8 had levels up to $55,000 \mathrm{dpm}$ beta.

\section{Hazardous Material Inventory}

The issue of hazardous constituents must be addressed in addition to the radioactive inventory. There is a potential to accumulate heavy metals in the bottom of tanks and in the gravity feed lines. Removal of the solids/ precipitants has been successfully accomplished in the 340-A tanks in the past. Experience from the $\mathrm{L}-070$ project revealed solids can be flushed from ines. Therefore only the vault/tanks within the RLWS may remain as areas of significant concern with regard to contaminated sediment/scale removal.

The facility clean-up must also address the issue of listed waste. Some streams entering the RLWS have been designated as F 1 isted wastes. This type of hazardous designation is independent of quantity or concentration, and is more difficult to address than characteristic wastes. All RLWS components must be considered listed waste due to the nature of past Pacific Northwest disposals (Pacific Northwest 1996c). After decon/cleanup the tanks, piping and other components could be evaluated for other beneficial uses under provisions of WAC 173-303 (Ecology 1995).

\subsubsection{Inventory Reduction Actions}

Preliminary evaluations of inventory reduction tasks have identified actions that will help minimize long term S\&M activities. Details of these actions are being developed and will be refined as additional information becomes available. Other options that may arise will be evaluated against these actions.

It is appropriate to flush out as much of the facility inventory as possible while the capability to remove the waste is readily available. The $340-\mathrm{A}$ 
tanks are primary candidates for flushing and the logical place to start. Much of the residual contamination was successfully removed in 1989 . Removing this material will reduce the dose rate to the surrounding area and could eliminate the need for active ventilation during the long term maintenance and surveillance phase. (WHC 1994c)

The sink/hood in the 340 Building decontamination area has had problems with contamination creeping out of the line and sink trap. To eliminate this, the hood should be decontaminated, flushed and the piping removed/capped where it enters the room. The removed equipment could be disposed of as radioactive waste. While this would eliminate the capability to sample the vault tanks using $T P-3$, the facility has an alternate sampling system that does not rely on $\mathrm{TP}-3$.

Once the hood/sink and the decontamination area have been cleaned up and waste no longer discharged to the RLWS from the sump, there may be justification to eliminate active ventilation of the 340 building. Again, this would reduce long term maintenance and surveillance.

The last sections in the 340 facility for clean-out would be the vault tanks and the load-out facility. A remote visual inspection is planned for the vault tanks. This inspection will determine whether there is sludge buildup inside the tanks. If the inspection shows significant quantities of siudge, the facility will evaluate whether it is possible to obtain a sample. If not, then an indium foil test or other external determination will be used to show that fissile material has not built up over the years. Based on the information, a determination can be made whether an acid flush is possible to remove the sludge and whether or not the tanks require active ventilation.

The equipment in 340-B east should be flushed to remove all residual waste. Once complete, in order to further cut down on exposure levels and risk of contamination spread in 340-B, the RLWS valves and piping should be removed and disposed of as low level waste. The platform should also be wiped down or decontaminated in the best manner possible, generating minimal liquid waste.

Facility status after these inventory reduction actions are completed, is anticipated as: 340-A (tanks \& building) -- cleaned so as to no longer require any radiation buffer zones, and drastically reduce S\&M needs (however, as is shown on the Figure 4-1 schedule, these tanks would still serve an emergency back-up to the vault tanks until 9/98); 340 Decon area and hood -- cleaned and or removed such that ventilation and current levels of S\&M are no longer needed; $340-B$ east -- cleaned to the point that ventilation and current S\&M are not required; and finally the 340 vault and tanks -- cleaned to where little S\&M is needed, and possibly the deactivation of the KI HVAC system.

\subsection{De-coupling RPS from RLWS}

This section discusses impacts on the RPS once 340 tanks are unavailable and proposes conceptual modifications to accommodate those needs. While most of the associated tasks fall within the near term period defined in Section 3.1 , they are segregated here due to a distinction from strict deactivation.

The RPS provides wastewater with an alternate route for disposal should significant radioactivity be detected. Currently, this other route is through 
WHC-SD-LEF-SSP-001, Rev. 0

the 340 RLWS tanks; and once the RLWS is shutdown, this path will be eliminated.

There are now two locations in the RPS system that allow waste to be routed away from the process sewer. The first is at the generator building. If radioactivity is detected at the building that RPS flow is diverted to the RLWS tanks. The remaining waste flows from the other buildings are not affected. This feature minimizes the volume of waste to be managed as RLW. The second location for waste diversion is the 307 basins. These basins are batch sampled for radioactivity. If radioactivity is detected, the contents of the basin may be pumped directly into the RLWS tanks.

The combined building flowrate into the 307 basins averages 50-60 gallons per minute. Each basin can effectively hold 25,000 gallons, thereby taking approximately 8 hours to fill. It then takes 1 hour to dry a sample and 1.5 hours to perform a sample count. The discharge pumps run at $-150 \mathrm{gpm}$, therefore, it takes -3 hours for transfer. By this time, the second basin is $70 \%$ full. It is obvious that fairly quick response actions must be taken in the event elevated radioactive levels are detected, or there may be multiple off-specification basins requiring special handling. This constraint is made more restrictive under the changes proposed in Section 3.3.1.

The 324 and 327 facilities are near the completion of their operating mission. They are expected to transition to the deactivation stage in October, 1996. Miscellaneous streams from cooling systems and the potential fire system activation requires continued RPS availability. The 324/327 facilities may eventually be de-coupled once cleaned to the point where they no longer pose a significant risk. The 329 and 326 facilities, while no longer requiring a RLWS line, are still hooked into the RPS diverter systems, and are expected to remain on the RPS diverter system. Therefore the $324,325,327,326$ and 329 buildings will be initially included in plans for the new 307 basin system that will capture any post-RLWS-shutdown diversions.

\subsubsection{Changes to Diverters and Associated Operational Controls}

The future operation of the basins will require cooperation between the 307 Basin operators and the RPS generator personnel. One operational plan calls for the dedication of one basin for containing the waste stream generated during building alarm situations. In a low cost version of this mode, an alarm from a building monitoring station, instead of. resulting in a divert to the RLWS, uses existing valving to direct the RPS flow at 307 to this dedicated basin ${ }^{4}$. A large drawback is that by diverting at the basins, the total RPS flow is now involved, not just that of the offending facility. The available capacity of a single basin will allow only -8 hours of response time. To retain sufficient RPS capability to support the non-offending facilities, the facility in alarm will be expected to curtail RPS flow. In the past, this has been accomplished by valving out the building water supply,

\footnotetext{
It has also been suggested that a new, high quality volve be installed on the RPS line, just upstream of the tie-in point for the batch-release composite sample pump, to direct flow to bas in \#4. A dedicated programable logic controller is also advised, and dedicated phone lines between 307 and the detectors would further improve reliability. Once this change is studied in more detail, it could prove to be more than just a simple re-programing of the existing alarm/valving system. In anticipation of this end, the number in Table 4-1 for RPS re-routing conservatively reflects the higher cost of such a design.
} 
however for reasons of safety this may not always be feasible (e.g., cooling water is needed for the high activity German canisters in 324). Another related $r$ isk is in using lines normally free of contamination, for waste with elevated levels. However, assuming the offending facility is shut down quickly, there should be several hours of flush time available to clear the lines. The VE study participants (mentioned in footnote 3 ) determined, and management concurred, that the risk from this mode of operation is both manageable and acceptable (Pacific Northwest 1996c).

Another option briefly considered was to retain use of the RLWS lines for building diverts, and only shunt the flow over to a dedicated 307 basin just prior to the 340 vault tanks. This avoids the combined volume problem noted above, but postpones deactivation of the RLWS, and retains the associated operational and maintenance costs. There is also some uncertainty regarding the impact of the mixed waste label attached to the RLWS system upon the possibility of adequately flushing the lines to dismiss this designation. The RLWS lines are part of a dangerous waste tank system, and if (WAC 173-303-200 l.b. ii may exempt) the tanks go through closure, then the ancillary equipment must also go through the closure process. Until negotiations on the need for a RCRA closure are conducted with Ecology, it is considered premature to plan on reusing any of the ancillary equipment.

A sub-option, suitable for the 325 building only after it acquires its new RLW tank, is to afford its operators the capability to manually initiate a divert of 325-RPS to its own 3000 gallon tank. A proposed automated version of this option was not supported (Pacific Northwest 1996c) due to the small size of the new tank. The feasibility and cost of a manual option should be weighed against potential savings involved in alleviating even a few upset burdens on the downstream system. The 325 laboratory can expect human error to contribute to diversions; such as moving a source too close to the RPS detector or rinsing contaminated equipment down the wrong drain. Therefore an automatic tie-in to the primary R.PS-to-307 option is still necessary for such situations, as well as for those involving divert volumes greater than the 325 RLW tank can handle.

One final upgrade that had been considered in support of basin operations was the installation of an on-line radiation monitor just before the RPS waste flow enters the basin header. This had been envisioned to both allow the basin operator to see real-time increases and decreases on the combined waste stream, and assist in the decision process associated with terminating diversion episodes. Inadequate detector sensitivity limits such usefulness, and such a monitor cannot be supported.

Recommendation: The baseline operation for the 307 basins will be to hold one basin in reserve for upsets detected at generating facilities. The entire RPS flow will be directed to this basin during the episode. 
WHC-SD-LEF-SSP-001, Rev. 0

\subsubsection{Basin Cover}

The retention basins have experienced solids accumulation. Past sampling results of the solids have also indicated low levels of radioactivity. A new aspect related to de-coupling is that one of the basins will now be called upon to receive RPS diversions, and that basin could contain potentially elevated levels of radiological contamination. The source of most of the solids is probably wind-blown sand in the open basins, al though the recent connection of some 340 area storm drain lines could contribute to this loading. The addition of a cover has been evaluated as one way to minimize surface dust and debris from entering the basins.

One cover option, a basic pre-engineered steel roof placed just over the outer perimeter of the 4 basins $\left(45^{\prime} \times 106^{\prime}\right)$, was estimated to cost $\$ 277,000$. This would not involve active ventilation, insulation, heating, nor any built-in lighting. Access would be provided by hatches (2 per basin, $3^{\prime} \times 4^{\prime}$ ) for potential cleaning, inspection, repairs, sampling, etc. However, this still represents a significant disadvantage over current, relatively unrestricted basin access, even hindering simple visual surveillance.

Another concept considered consisted of a pre-engineered (Butler-type) steel building (walls $10^{\prime}$ high, dimensions 55' $x 116^{\prime}$ ) around all 4 basins with room for a perimeter walkway; estimated at $\$ 390,000$. This would include standard incandescent lighting and a set of double doors at each end, but again, no active ventilation, heating, nor insulation. Access is improved and the basin pumps and personnel are afforded an added degree of protection from weather extremes. Non-rigid, fabric structures were briefly contemplated but dismissed as insubstantial.

To help place these costs in perspective, the typical cost for cleaning out all four basins (including sampling and analys is and sludge disposal) is only around $\$ 9400$. It would be difficult to justify the expense of either cover from the standpoint of sediment control, especially since the need for periodic basin cleaning would still remain to some degree.

As far as contamination control, the safety evaluation for the RPS system (Berneski 1995) took no credit for upstream diversion, and thus effectively addressed conditions under the de-coupling proposal. That analysis determined the RPS was below hazard category 3 and non-nuclear.. Other benefits of a cover, such as worker and equipment protection from weather extremes (more so for the building version) and the exclusion of wildlife, are not deemed sufficient to offset construction costs.

Recommendation: Basin covers of any type cannot be justified.

\subsubsection{Truck Load-out Station}

The planned deactivation of 340 vault tanks and 340-B east will require an a) ternate method for removal of contaminated water from the basins. It is expected that RL will announce a pian to end railroad operation under a phased withdrawal. A loss of rail service would impact future shipments from the $340 / 307$ Complex. A truck load-out station is the anticipated solution. 
Although a detailed analysis of options is being conducted, some preliminary considerations are discussed here.

A stand-alone truck port could be envisioned as a Butler building type of structure. It would require enough space to handle either the $1000 \mathrm{gal}$ LR-56, the $5000 \mathrm{gal} \mathrm{C}-018 \mathrm{H}$ trailer, or the $10,000 \mathrm{gal} \mathrm{MC}-312$ tanker (and might be sized to accommodate the treatment package described in Section 3.3.4). There is sufficient land just east of the basins (see Figure 2-1), along with an access corridor for trucks east of 340-A. The floor would consist of some sort of sloped/curbed concrete pad with a sump to contain spills. Including standard lighting provisions, but without any special ventilation or insulation, the estimated cost is $\$ 160 \mathrm{k}$.

The use of an existing facility such as 340-B east was reviewed. The present pathway for loading out any basin solutions via 340-B involves passage through the vault tanks. Another route and motive force would be needed, which could impede other deactivation activities occurring in the area between 307 and $340-B$. This option could complicate the final turn-over of the 340 Facility for decommissioning, and the implementation phase could interfere with the 90day window shipment schedules.

Recommendation: A separate load-out station adjacent, and to the east of the 307 basins is the preferred baseline recommendation. It shall be flexible enough to accommodate all realistic, available tanker trailers on site.

\subsubsection{Stand-by Treatment}

Operation of the 307 basins under the more sensitive detection limits afforded by the RPS monitor upgrade (WHC 1995a), as well as the batch release system (WHC 1993a), increases the potential for off-specification basins. The conditions found post-shutdown, where upstream RPS monitor trips divert the entire RPS flow, could also increase the volume of diverted waste. Options available include blending with lower level batches, disposal through the 200 Area double-shell tank pathway, and treatment at either the 200 Area Effluent Treatment Facility (ETF) or within the 300 Area.

The previous recommendation to maintain a transportation option to the 200 Area remains a prudent measure, especially where treatment of higher activity wastes at a 307 facility, could increase worker exposure. On the other hand, truck shipments represent a costly prospect for large volumes of marginally contaminated waste. When including subsequent waste disposal through the 242A evaporator, ETF, and glass plants, estimates of the overall costs can run as high as $\$ 180 /$ gallon. Even using the $\$ 20 /$ gal double shell tank user fee Tank Waste Remediation System's (TWRS) had once proposed charging generators, avoiding a single basin load transfer to the 200 Area could justify some basic contingency treatment provisions.

5

If the ETF was able to accept non-routine wastes (either through blending in their surge tank or in a Liquid Effluent Retention Facility basin), it could represent a still lower cost option than through the 204-AR pathway. 
Ful1-spectrum treatment is not needed nor especially desired. The selective removal of radionuclides is the fundamental need. The 300 Area TEDF is equipped to deal with residual chemical contaminants; and total contaminant removal could generate excessive secondary solid wastes.

Radionuclide-containing waste waters generated in the 300 area may contain mixed fission products, as well as alpha emitting isotopes of plutonium, americium, and uranium. The underlying matrix in which the radionuclides are contained will primarily be sanitary water, with low levels of non-radioactive contaminants, dependant on the research being conducted at PNNL. Nonradioactive contaminants may include dissolved solids, suspended solids, and traces of organics and heavy metals. Treated effluent could be returned to the RPS flow upstream of the in-line basin sampler for a confirmation check, prior to discharge to TEDF'.

One proposal considered is the iristallation of a stand-by, permanently installed treatment system. The system would employ a filtration system with the capability to remove a full range of particle sizes, and approximately 6-8 columns suitable for use with a variety of resins and adsorbents. Use of a particular resin or adsorbent would depend on the nature of the wastes to be treated. Resins and adsorbents would be disposed of as waste, rather than regenerated. As noted earlier, the system could be co-located in the truck load-out. Design details such as flow rate, filter methods, resin and/or adsorbent types, and needed weather-proofing, secondary containment, controls, and monitors, will have to considered before any firm cost estimates can be made. Flexibility is considered essential, as the volume and make-up of effluent requiring treatment cannot be precisely predicted in advance. This system is estimated to cost $~ \$ 600 K$.

A second, lower capital cost treatment option utilizes a permanently installed filtration system and commercially available complete demineralization columns that would be employed on a "use/dispose" basis. Complete demineralization removes all contaminants of concern to TEDF acceptance criterja, and recognizes the limited shelf lives of many specialized resins ${ }^{7}$. The relative increase in solid wastes is a factor, but the disposal costs of secondary wastes are $\$ 200 /$ drum. If 1 iquid in the basins requires treatment, IX columns from a local vendor may be purchased for $\$ \$ 1,200$. These columns can treat approximately $10,000 \mathrm{gal}$ of $75 \mathrm{prm}$ alkalinity water, with the end product being 18 Megohm water. The number of columns required will depend on total dissolved solids loading in the basin water, and the. loaded columns would be disposed of as solid waste. A rough order of magnitude cost estimate for installation of this system is around $\$ 200 \mathrm{k}$. Costs above do not reflect the air permitting and other regulatory tasks captured el sewhere.

\footnotetext{
6 This return line could share a trench with the proposed new RPS diversion line to besin \#4, discussed in footnote 4 (Section 3.3 .1 ).

7

Most ion exchange resins need to be stored in a layup condition, which requires regeneration prior to use. An alternative to this would be to store the resins in a layup solution containing biocides, but the resins would still require significant flushing prior to use. Purchase of specialty resins on a short turnaround basis may be an at ternative to storing resins, but procurement of the specialty resins may prove difficult.
} 
Either of these options, coupled with the truck load-out, provide a means of removing contaminated liquids from the 307 basins. The truck option alone does not provide an efficient capability to remove large quantities of water, and the treatment options should not be used to handle highly contaminated wastes due to exposure concerns. A combination of the shipment and the low capital cost treatment option provides the most cost effective means of disposal of contaminated basin water.

Recommendation: Purchase and install the basic superstructure for the lowcost package treatment system, along with needed pumps and piping for feed, return, and drain functions.

\subsection{Interim maintenance \& surveillance}

With the facility inventories stabilized, the facility will begin systematically deactivating non-essential systems. ER prefers that water supply, fire protection, HVAC, and electrical systems/services be reduced to the maximum extent possible (DOE 1995b). ER normally asks that emergency lighting systems be removed, electrical service controls be centralized, any loose asbestos be removed, and any equipment/systems that might be needed during later D\&D be mothballed according to manufacturers recommendations. This type of thinking is factored into the following building-specific reviews.

Without waste in the 340-A tanks there is no need for facility heating, leak detection/alarm capability and area radiation monitors. It is possible that the tanks will not require active ventilation.

When 340-B east is deactivated there will be no need for leak detection/alarm capabilities, area radiation monitoring, and the $\mathrm{K}-2$ ventilation system. The ventilation filters would be removed and disposed of as waste. The heaters can be deactivated, the process water valved out and the 1 ines drained. A sanitary water leg into the building must be isolated and removed. The continued need for active smoke detection, after combustible material are removed from the facility, requires further evaluation.

The future use of the 340 building must be determined before approaching deactivation of essential systems. The facility is equipped with process water and fire sprinkler protection. This may be of use as an indoor storage area for basin activities. Decontaminating the 340 decon area and removing the sump, hood, and associated lines may be sufficient to justify completely deactivating the $\mathrm{K}-3$ ventilation system. The filters would be removed and disposed of as waste. Portions of the ventilation may remain active for heat/cooling if the facility is to remain in use. Sprinkler and process water systems should be drained before eliminating the heat portion of the ventilation.

It is difficult to predict whether the ventilation system will be required for the 340 vault tanks once the system is flushed. A clean-out goal could be to reduce the source term (through tank flushing, vault decon, and perhaps HEPA filter change-out) at least sufficient to drop the 340-NT-EX stack from the WOOH register of major stacks. This would eliminate the need for stack monitoring as well as the potential need for any HEPA filter housing upgrades. 


\section{WHC-SD-LEF-SSP-001, Rev. 0}

Upgrades for remote monitoring may still be needed to minimize facility inspections.

The facility is currently inspected daily, seven days a week. This inspection covers operations equipment as well as the essential systems defined earlier. As systems are phased out the inspection frequency may be reduced. The long term goal is to reduce or eliminate facility inspection for the period leading up to final decontaminating \& decommissioning.

Other conditions that are expected (DOE 1995b) upon completion of deactivation include: removal of all unneeded supplies/spares/tools, closing all building penetrations, repairing any roof leaks, servicing monitoring systems, cleaning and releasing radiological zones, ensuring drawings are up-to-date, finalizing outstanding $U 0, \mathrm{~N}$, and other occurrence reports, and securing all entrances. The schedule in 4.0 lumps these activities under "Misc. Deactivation Tasks"; where details await scheduling in the PMP and other later documents.

\subsection{Budget process}

Preliminary cost projections for tentative work scope have been developed via Basis of Estimate worksheets. These will be incorporated through the normal budget process which utilizes Activity Data Sheets (ADS), Risk Data Sheets (RDS), and the multi-year program plan (MYPP). Budget planning takes place in the year(s) preceding actual work. Funding is subject to changes in

availability with each fiscal year. The shutdown of 340 is new work scope and funding sources are currently under development. 
WHC-SD-LEF-SSP-001, Rev. 0

This page intentionally without substantive content. 


\subsection{SUMMARY SCHEDULE/BUDGET}

This section provides a schedule/budget synopsis of the principle undertakings associated with this plan. The activities associated with the deactivation of 340 , as outlined in the four sub-sections of 3.0 , fall into the following basic areas:

Interim operation

- run-to-fail classification

- preventive maintenance on essential SSCs only

- Record Management updates

- prepare project management plan

Deactivation of 340 , decon area and vault, 340-A, and 340-B east

- blank RLWS lines

- terminal clean-out of wastes

- process equipment/material surplusing

Replacement for 340 and rail services

- RPS re-routing and de-coupling

- 307 load-out and standby treatment facility

- includes the 325 upgrade and 204-AR modifications

Preparations for S\&M phase

- negotiate end-point criteria

- evaluate and effect upgrades to facilities/support systems

Figure 4-1 presents these activities on a detailed schedule using PX (Project $2 /$ Series $X$ ) scheduling software. Table 4-1, following the out line of Figure 4-1, summarizes some of the preliminary cost estimates available at this time for most of the tasks. Note that this integrated 1 ist includes baseline operating and maintenance budgets which are currently identified in MYPP planning documents, as well as other costs (such as for the 204-AR and 325 laboratory modifications) that fall largely ${ }^{8}$ outside the scope of this plan. ICF-Kaiser Hanford cost estimating services assisted in the development of the "study estimates" that support most of the values presented in Table 4-1.

As is obvious from the assumptions presented in 1.3, changes in budget, rail availability, lab missions, waste volumes, regulations, etc., could impact these projections. Also, certain tasks (such as preparations for the S\&M phase) must await the results of intervening work (in this example, acceptable end-point criteria, and facility condition post-rco) before they can be scoped with any confidence. Therefore, as this effort proceeds, official budget planning instruments (see 3.5 ) should be consulted for better break-out and more up-to-date information. Subsequently planned project and programmatic decommissioning documentation will also provide more detail.

\footnotetext{
8

Some of the aforementioned baseline O\&M costs may be impacted by activities proposed by this plan (e.g., greater need for revising the safety biasis, added waste samples, increased work package preparation and tracking, etc.), and its also possible that design work associated with the latter projects could be adopted for some of the 340 efforts.
} 


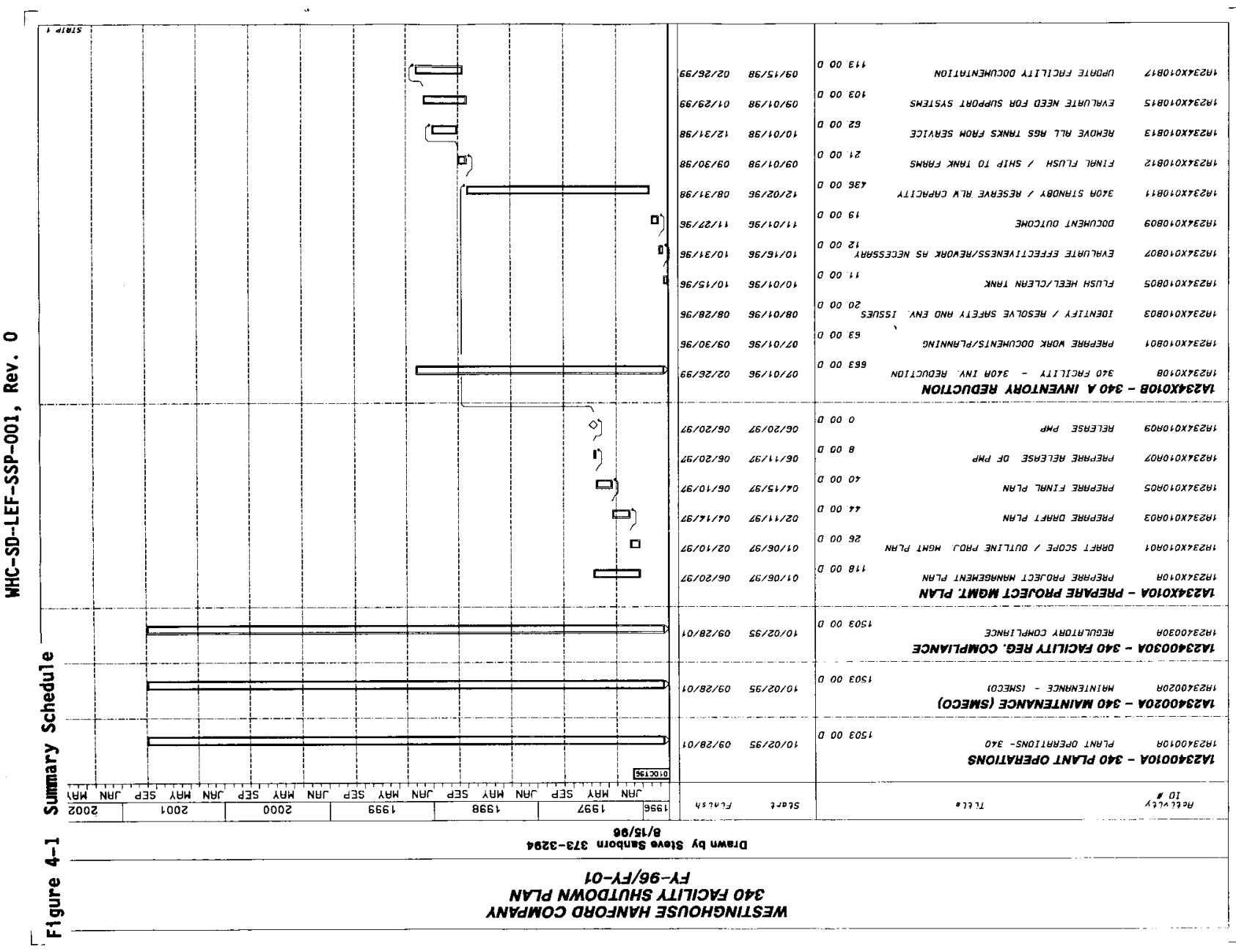




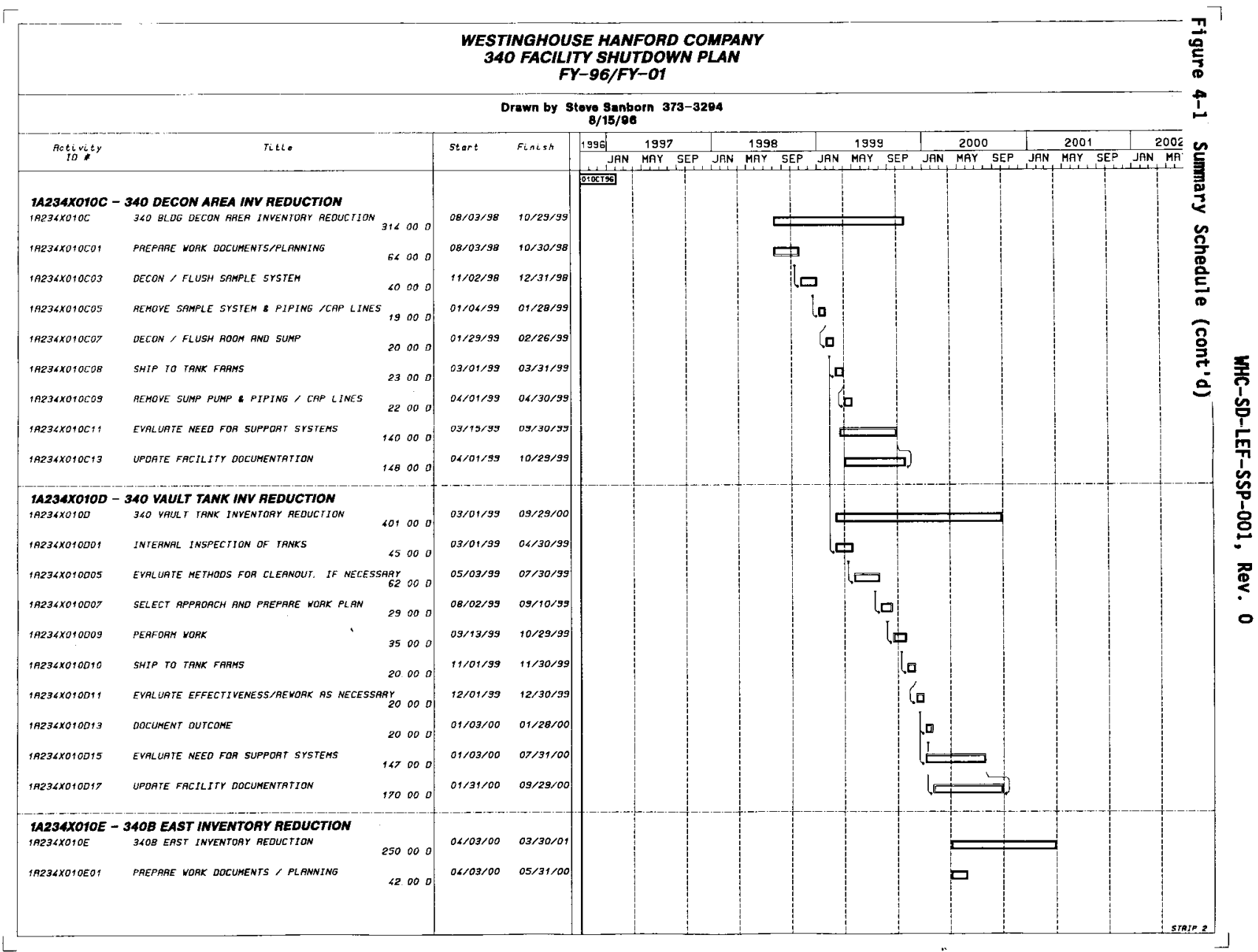




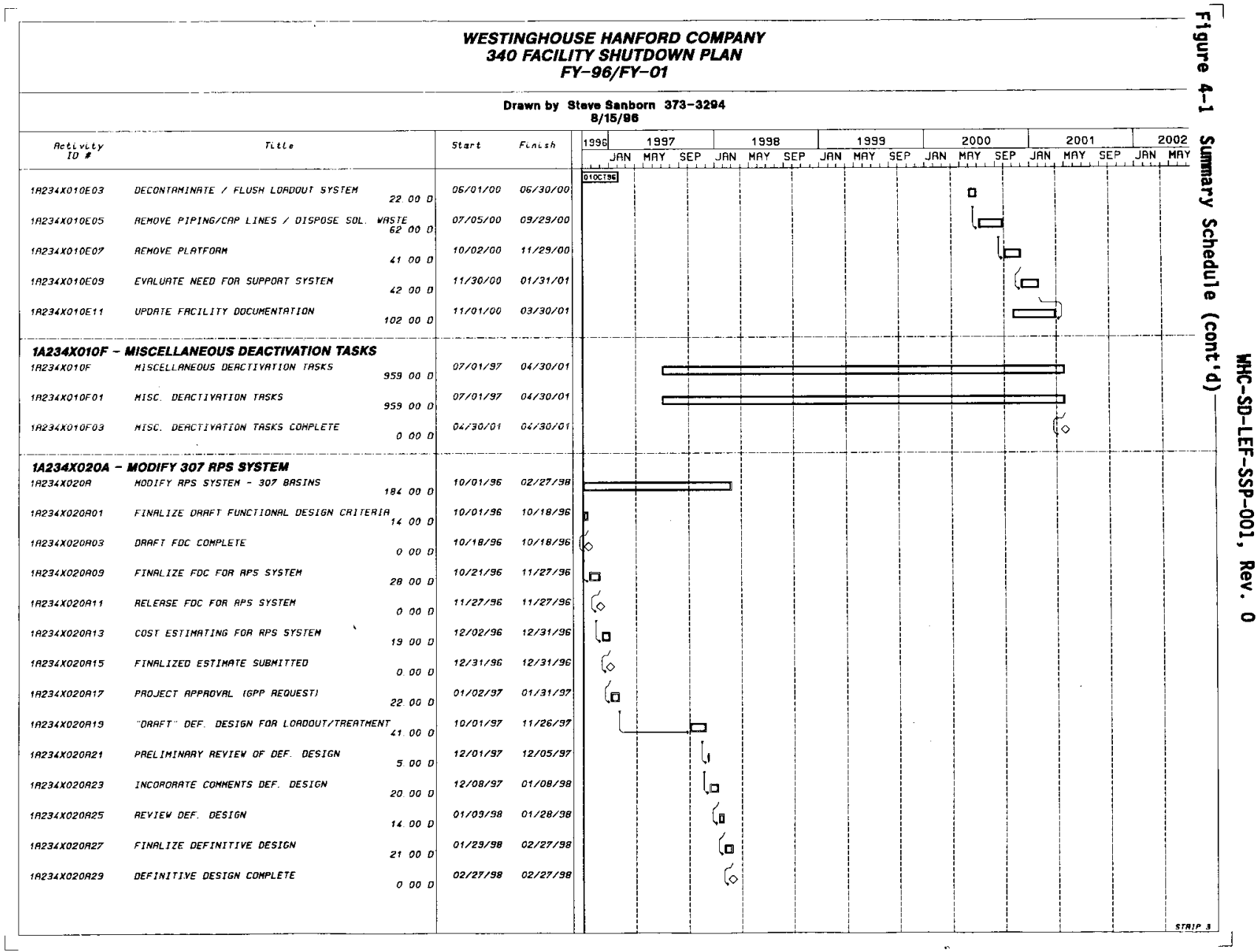




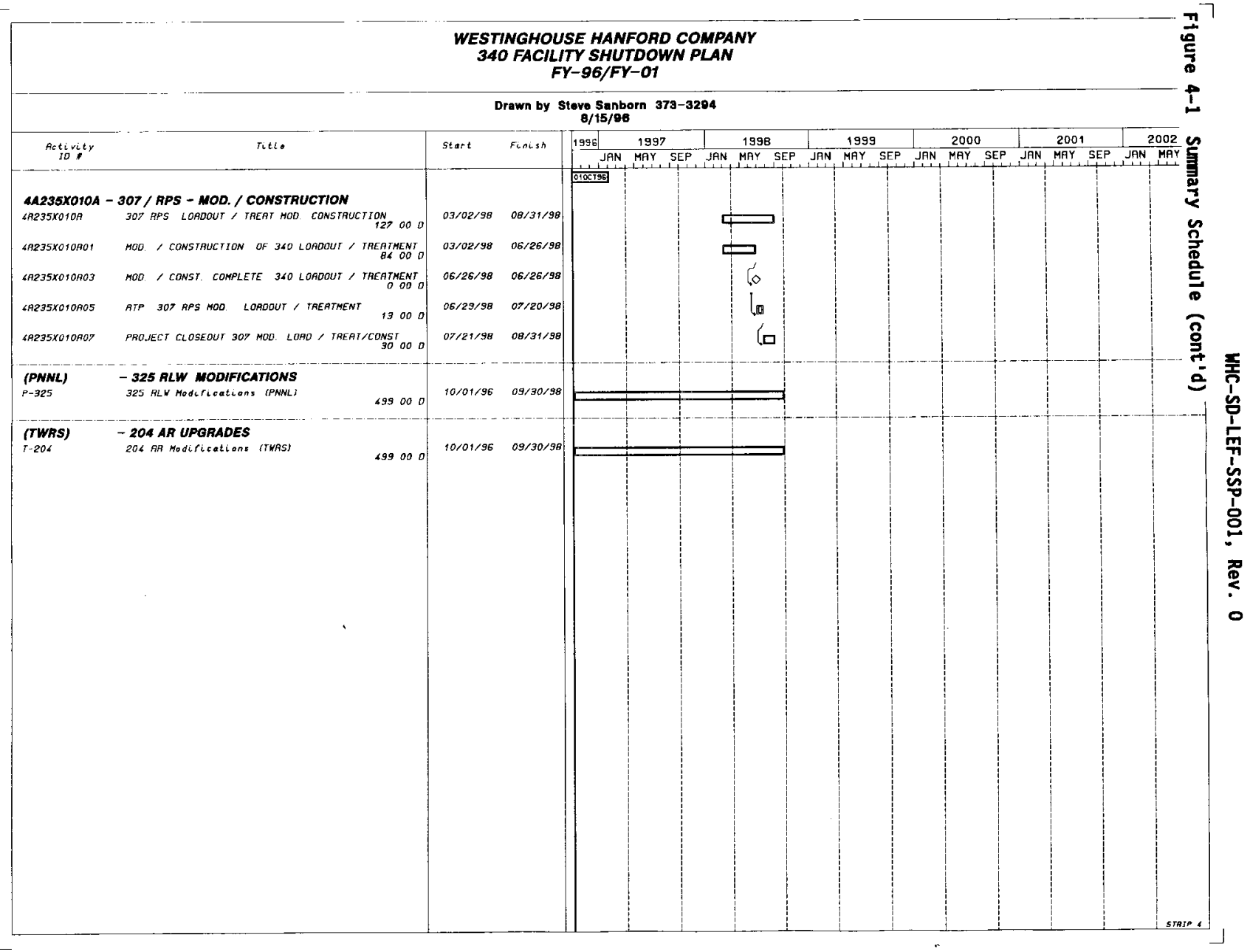




\begin{tabular}{|c|c|c|c|c|c|c|c|}
\hline \multirow{3}{*}{ Activity } & \multicolumn{7}{|c|}{ Budget Estimates (in $\$ 1000$ s) } \\
\hline & \multicolumn{2}{|c|}{ FY 197} & \multicolumn{2}{|c|}{ FY ' 98} & \multicolumn{2}{|c|}{ FY '99-' 01} & \multirow{2}{*}{ Total } \\
\hline & Expense & Capital & Expense & Capital & Expense & Capital & \\
\hline SMECO ${ }^{1}$ (O\&M baseline) & 3620 & & 3660 & & 10,900 & & 18,200 \\
\hline Addt1. regulatory supp ${ }^{2}$ & 50 & & 50 & & & & 100 \\
\hline 340-B fire sys. $(W-500)$ & & 75 & & & & & 75 \\
\hline 340-A Inventory Reduct. & 120 & & 130 & & 30 & & 280 \\
\hline 340 Decon Area I.R. (") & & & 32 & & 180 & & 212 \\
\hline 340 Vault tank I.R. (") & & & & & 414 & & 414 \\
\hline 340-B Load-out I.R. (") & & & & & 474 & & 474 \\
\hline Modify $307 /$ RPS system ${ }^{3}$ & 458 & & & 387 & & & 845 \\
\hline Support sys mods $(E R C)^{4}$ & & & & & $-\cdots$ & --- & TBD \\
\hline Modify 204-AR (TWRS) & --- & & --- & & & & 1000 \\
\hline \multirow[t]{2}{*}{ Modify $3251 \mathrm{ab}$ (PNNL) } & $\ldots$ & & & --- & & & 1900 \\
\hline & : & & & & & & \\
\hline \multicolumn{7}{|c|}{ Grand Total } & 23,500 \\
\hline \multicolumn{7}{|c|}{ Grand Total (minus SMECO) } & 5300 \\
\hline \multicolumn{8}{|c|}{$\begin{array}{l}\text { 'Safe Minimum Environmentally Compliant Operations -- Covers normal operation \& maintenance (operators, } \\
\text { admin., sampling, audits, safety basis updates, rail shipments (only thru FY98), reg. compliance,...). }\end{array}$} \\
\hline \multicolumn{8}{|c|}{${ }^{2}$ This reflects non-SMECO, new-307 facility related, regulatory costs: NOC, NEPA (EA), \&/Or RCRA. } \\
\hline \multicolumn{8}{|c|}{${ }^{3}$ Includes RPS re-routing \& de-coupling; plus new 307 Basin's truck load-out/standby treatment facility. } \\
\hline
\end{tabular}




\subsection{REFERENCES}

ANSI 1978, Radiation Protection Instrumentation Test and Calibration, ANSI N323-1978, American National Standards Institute, New York, New York.

Berneski, L.D. 1995, Hanford 300 Area Retention Process Sewer - Inventory at Risk Calculations and Safety Analysis, WHC-SD-WM-SAD-027, Rev. 0, Westinghouse Hanford Company, Richland, Washington.

DOE 1989, General Design Criteria, DOE Order 6430.1A, U.S. Department of Energy, Washington, D.C., Apri1 6, 1989.

DOE 1993, Fire Protection, DOE Order 5480.7A, U.S. Department of Energy, Washington, D.C., February 17, 1993.

DOE 1995a, Facility Deactivation End Points Handbook, 3rd Draft - "for Use and for Comment", EM-60, Office of Nuclear Material and Facility Stabilization, U.S. Department of Energy, Washington, D.C., November 16, 1995.

DOE 1995b, Decommissioning Resource Manual, DOE-EM-0246, EM-40, Office of Environmental Restoration, U.S. Department of Energy, Washington, D.C., August, 1995.

Ecology 1995, Dangerous Waste Regulations, Chapter 173-303 of the Washington Administrative Code, State Department of Ecology, 0lympia, Washington.

Ecology, EPA, and DOE 1989, Hanford Federal Facility Agreement and Consent Order, Washington State Department of Ecology, U.S. Environmental Protection Agency, and the U.S. Department of Energy, 01ympia, Washington.

Ecology, EPA, and DOE 1995, Tentative Agreement on Amendment Six to the TriParty Agreement, Section 8.0, "Facility Decommissioning Process", WA State Dept. of Ecology, U.S. Envirorimental Protection Agency, and the U.S. Dept. of Energy, Richland, Washington, November 1995.

EPA 1989, 40 CFR 60, Standards of Performance for New Stationary Sources, Title 40, Code of Federal Regulations, Part 60, as amended, U.S. Environmental Protection Agency, Washington, D.C.

EPA 1991, National Emission Standards for Hazardous Air Pollutants, Title 40, Code of Federal Regulations, Part 61, U.S. Environmental Protection Agency, Washington, D.C.

Ha11, R. B. 1978, Ground Contamination Beneath RLW Tee at 340, TC-1040, Westinghouse Hanford Company, Richland, Washington.

Pacific Northwest 1989, RLWS Disposal Approval Requests, Pacific Northwest Laboratory, Richland, Washingtion.

Pacific Northwest 1996a, Letter (Incoming 9600138) "Integration of 325/340 Facility Recommendations with the 324/327 Facility Transition Recommendations", M.J. Bagagl io to A.J. DiLiberto, January 16, 1996, Pacific Northwest National Laboratory. 
WHC-SD-LEF-SSP-001, Rev. 0

Pacific Northwest 1996b, Letter "Request for 325 Building Waste Operations Plan Due to the 340 Waste Handling Facility Shutdown", W.J. Apley to R.F. Christensen (RL), May 20, 1996, Pacific Northwest National Laboratory.

Pacific Northwest 1996c, Letter "Review and Comments of the 340 Waste Handling Facility Deactivation Plan", W.J. Apley to A.J. Diliberto, August 6, 1996, Pacific Northwest National Laboratory.

RL 1996, Letter (Incoming 9601262) "Proposal for Meeting Performance Based Fee Criteria Number 96-808: Prepare a 340 Waste Handling Facility Shutdown P]an", T.K. Teynor to President WHC, May 21, 1996, DOE-Richland Operations office.

Roberts, L.W. 1995, 340 Complex Fire Hazard Analysis, WHC-SD-WM-FHA-011, Rev. 0 , prepared by Hughes Associates, Inc., Columbia, Maryland, for Westinghouse Hanford Company, Richland, Washington.

WHC 1990a, HVAC HEPA Filter Modification Decontamination Area, H-3-52425, Westinghouse Hanford Company, Richland, Washington.

WHC 1990b, Management Requirements and Procedures, WHC-CM-1-3, MRP 6.15, "Facility Shutdown, Standby, and Transfer", Westinghouse Hanford Company, Richland, Washington, January 1990.

WHC 1992a, Fire Protection Program Manua 7, WHC-CM-4-41, Westinghouse Hanford Company, 1992.

WHC 1992b, Past Practices Technical Characterization Study - 300 Area Hanford Site, WHC-MR-0388, Westinghouse Hanford Company, December 1992.

WHC 1993a, Functional Design Criteria, 307 Basin Maintenance Upgrades, Project 94-EWW-345, WHC-SD-W345-FDC-001, Rev. 0, Westinghouse Hanford Company, Richland, Washington, May, 1993.

WHC 1993b, Technical Requirements Document for use of the RLWS and RPS, WHC-SD-WM-TI-468, Rev. 2, Westinghouse Hanford Company, Richland, Washington, JuTy, 1993.

WHC 1994a, Engineering Practices Guidelines, WHC-IP-1026, Rev 0, Westinghouse Hanford Company, Richland, Washington, May 27, 1994.

WHC 1994b, Nuclear Criticality Safety Manual, WHC-CM-4-29, Rev. 1, Westinghouse Hanford Company, Richland, Washington, May 23, 1994.

WHC 1994C, Internal Memo 86700-94-057, "Use of Water for Shielding in 340A Above Ground Storage Tanks," D. W. Lindsey to D. J. Carrel1, May 27, 1994.

WHC 1994d, 300 Area Liquid Effluent Facilities Administration, WHC-IP-1000, Westinghouse Hanford Company, Richland, Washington, September 16, 1994.

WHC 1995a, Conceptual Design Report: 300 Area Diverter Station Upgrade; Project W-353, prepared for WHC by ICF Kaiser Hanford Co., January 1995. 


\section{WHC-SD-LEF-SSP-001, Rev. 0}

WHC 1995b, Training Implementation Matrix Per DOE Order 5480.20A: 340 Waste Handling Facility, Rev. la, R.B. Barmettler, Westinghouse Hanford Co., January 1995.

WHC 1995c, 340 Waste Handling Facility Comparison with 40 CFR 61, Subpart H and Other Referenced Guidelines for Stack 340-NT-EX, WHC-EP-0544, Westinghouse Hanford Company, Richland, Washington.

WHC 1995d, Work Management, WHC-CM-1-8, Westinghouse Hanford Company, Richland, Washington.

WHC 1995e, 340 Waste Handling Facility Interim Safety Basis, WHC-SD-WM-ISB003, Rev. 0, Westinghouse Hanford Company, Richland, WA, April 1995.

WHC 1996a, Criticality Safety Evaluation Report for 340 Facility, WHC-SD-SQACSA-20379, Rev. 1, Westinghouse Hanford Company, Richland, Washington.

WHC 1996b, 340 Facility Waste Tank System Integrity Assessment Report, WHC-SDWM-ER-546, Rev 0, E.J. Walter, WHC, Richland, Washington, May 15, 1996.

WHC 1996c, Facility Effluent Monitoring Plan for the 340 Waste Handling Facility, WHC-EP-0469-2, Westinghouse Hanford Company, Richland, Washington, Apri1 1996

WHC 1996d, HVAC Air Flow \& Control Diagrams, H-3-34404, WHC, Richland, WA.

WHC 1996e, Work Management Guidance, WHC-IP-1217, Westinghouse Hanford Company, Richland, Washington.

WHC 1996f, Environmental Compliance, WHC-CM-7-5, Westinghouse Hanford Company, Richland, Washington.

WHC $1996 \mathrm{~g}$, Statement of Work for Analytical Services Provided to WHC by the Pacific Northwest Analytical Laboratory, WHC-EP-0857-1, J.K. Perry, Westinghouse Hanford Company, Richland, Washington, May 1996. 